Cover. View of the Willamette River facing upstream, near Harrisburg, Oregon. Photograph by Tobias J. Kock, U.S. Geological Survey, May 7, 2019. 


\section{Synthesis of Habitat Availability and Carrying Capacity Research to Support Water Management Decisions and Enhance Conditions for Pacific Salmon in the Willamette River, Oregon}

By Tobias J. Kock, Russell W. Perry, Gabriel S. Hansen, James White, Laurel Stratton Garvin, and J. Rose Wallick

Prepared in cooperation with the U.S. Army Corps of Engineers

Open-File Report 2021-1114 


\section{U.S. Geological Survey, Reston, Virginia: 2021}

For more information on the USGS - the Federal source for science about the Earth, its natural and living resources, natural hazards, and the environment—visit https://www.usgs.gov or call 1-888-ASK-USGS.

For an overview of USGS information products, including maps, imagery, and publications, visit https://store.usgs.gov/.

Any use of trade, firm, or product names is for descriptive purposes only and does not imply endorsement by the U.S. Government.

Although this information product, for the most part, is in the public domain, it also may contain copyrighted materials as noted in the text. Permission to reproduce copyrighted items must be secured from the copyright owner.

Suggested citation:

Kock, T.J., Perry, R.W., Hansen, G.S., White, J., Stratton Garvin, L., and Wallick, J.R., 2021, Synthesis of habitat availability and carrying capacity research to support water management decisions and enhance conditions for Pacific salmon in the Willamette River, Oregon: U.S. Geological Survey Open-File Report 2021-1114, 24 p., https://doi.org/10.3133/ofr20211114.

ISSN 2331-1258 (online) 


\section{Acknowledgments}

We extend a special thanks to Rich Piaskowski, Jake MacDonald, and Rachel Laird for their interest and involvement in this effort. Several people provided insights and knowledge about the Willamette River that aided in this process including Luke Whitman and Brian Bangs with the Oregon Department of Fish and Wildlife and Stan Gregory with Oregon State University. 



\section{Contents}

Acknowledgments ……...................................................................................................................

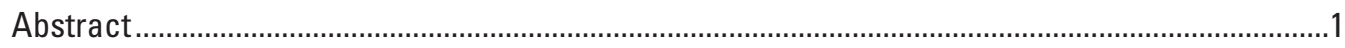

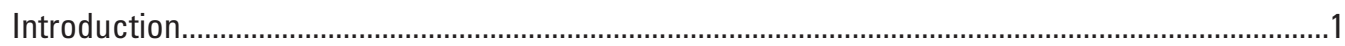

Objective 1-Review Existing Willamette River Datasets and Identify Key Data Gaps ....................4

Existing Studies and Datasets ...............................................................................................

Objective 2—Summarize Methods to Estimate Habitat Availability ...............................................

Habitat Suitability Criteria ................................................................................................

Logistic Regression Models................................................................................................11

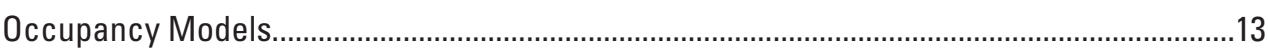

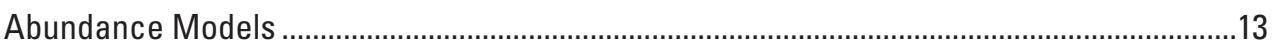

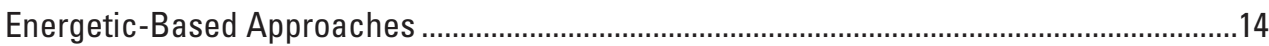

Objective 3-Identify Optimal Methods for Estimating Carrying Capacity and its Influence on Density-Dependent Processes in the Willamette River and its Major Tributaries.........14

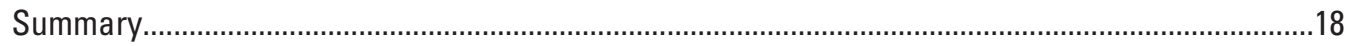

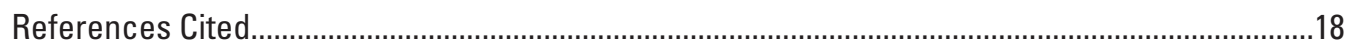

\section{Figures}

1. Map showing the Willamette River Basin in western Oregon, highlighting the river network and locations of Willamette Project dams operated by the U.S.

Army Corps of Engineers.

2. Image showing an example of the SLICES framework from the mainstem Willamette River Basin ...

3. Schematic showing a conceptual hierarchy of five contemporary habitat assessment methods ranging from less complex to more complex, including relative data requirements and the relative inference of each approach to a given population...

4. Graphs showing science of the Willamette Instream Flows Team habitat criteria represented as univariate Habitat Suitability Indices for the median category for Chinook salmon fry

5. Graphs showing univariate habitat suitability curves for depth, velocity, and distance to cover fitted to presence-only observations of juvenile Chinook salmon fry and parr in the Klamath River, California, using methods of Som and others (2016)

6. Graph showing Beverton-Holt model showing the linkages between habitat area, maximum density per unit of suitable habitat area, carrying capacity and their influence on density-dependent population dynamics.

7. Graph showing a hypothetical four-stage population illustrating the linkage between capacity and time.

\section{Table}

1. Summary of previous studies conducted in the Willamette River Basin that were reviewed to determine if data and results could be used in future assessment of habitat availability in the basin 


\section{Conversion Factors}

U.S. customary units to International System of Units

\begin{tabular}{|c|c|c|}
\hline Multiply & By & To obtain \\
\hline \multicolumn{3}{|c|}{ Length } \\
\hline foot $(\mathrm{ft})$ & 0.3048 & meter (m) \\
\hline mile (mi) & 1.609 & kilometer (km) \\
\hline
\end{tabular}

International System of Units to U.S. customary units

\begin{tabular}{lcl}
\hline \multicolumn{1}{c}{ Multiply } & By & \multicolumn{1}{c}{ To obtain } \\
\hline centimeter $(\mathrm{cm})$ & Length & \\
meter $(\mathrm{m})$ & 0.3937 & inch $(\mathrm{in})$. \\
meter $(\mathrm{m})$ & 3.281 & foot $(\mathrm{ft})$ \\
kilometer $(\mathrm{km})$ & 1.094 & yard $(\mathrm{yd})$ \\
kilometer $(\mathrm{km})$ & 0.6214 & mile $(\mathrm{mi})$ \\
& 0.5400 & mile, nautical $(\mathrm{nmi})$ \\
\hline liter $(\mathrm{L})$ & Volume & \\
\hline & 33.81402 & ounce, fluid $(\mathrm{fl} . \mathrm{oz})$ \\
\hline meter per second $(\mathrm{m} / \mathrm{s})$ & Flow rate & foot per second $(\mathrm{ft} / \mathrm{s})$ \\
cubic meter per second $\left(\mathrm{m}^{3} / \mathrm{s}\right)$ & 3.281 & cubic foot per second $(\mathrm{ft} 3 / \mathrm{s})$ \\
\hline
\end{tabular}

Temperature in degrees Celsius $\left({ }^{\circ} \mathrm{C}\right)$ may be converted to degrees Fahrenheit $\left({ }^{\circ} \mathrm{F}\right)$ as follows:

$$
{ }^{\circ} \mathrm{F}=\left(1.8 \times{ }^{\circ} \mathrm{C}\right)+32 .
$$

\section{Datums}

Vertical coordinate information is referenced to the North American Vertical Datum of 1988 (NAVD 88).

Horizontal coordinate information is referenced to the North American Datum of 1983 (NAD 83). 


\section{Abbreviations}

$2 D$

BiOp

CSI

ESA

HSC

HSI

IFIM

NMFS

ODFW

PHABSIM

RHABSIM

R2

SWIFT

Reclamation

USACE

USFS

UWR two-dimensional

Biological Opinion

composite suitability index

U.S. Endangered Species Act

habitat suitability criteria

habitat suitability index

instream flow incremental methodology

National Marine Fisheries Service

Oregon Department of Fish and Wildlife

Physical Habitat Simulation System

River Habitat Simulation Model

R2 Resource Consultants, Inc.

Science of the Willamette Instream Flows Team

Bureau of Reclamation

U.S. Army Corps of Engineers

U.S. Forest Service

Upper Willamette River 



\title{
Synthesis of Habitat Availability and Carrying Capacity Research to Support Water Management Decisions and Enhance Conditions for Pacific Salmon in the Willamette River, Oregon
}

\author{
By Tobias J. Kock, Russell W. Perry, Gabriel S. Hansen, James White, Laurel Stratton Garvin, and J. Rose \\ Wallick
}

\section{Abstract}

Flow management is complex in the Willamette River Basin where the U.S. Army Corps of Engineers owns and operates a system of 13 dams and reservoirs (hereinafter Willamette Project), which are spread throughout three large tributaries including the Middle Fork Willamette, McKenzie, and Santiam Rivers. The primary purpose of the Willamette Project is flood-risk management, which provides critical protection to the Willamette Valley, but flow managers must also consider factors such as power generation, waterquality improvement, irrigation, recreation, and protection for aquatic species such as U.S. Endangered Species Act-listed Chinook salmon (Oncorhynchus tshawytscha) and steelhead (O. mykiss). Flow-management decision-making in the basin can benefit from models that allow for flow-scenario comparisons and a wide range of modeling methods are available. For this study, we examined existing datasets and modeling efforts in the basin and provided an overview of available options. Most previous studies used Physical Habitat Simulation System, habitat data were collected from a series of transects within modeled reaches, and habitat suitability indices were obtained from the literature, or using expert opinion. These studies provide information for specific reaches of the Willamette River Basin, which limits their ability to provide broad-scale predictive capability. Recent efforts to develop a two-dimensional hydraulic model in the mainstem Willamette River, and in specific reaches of primary tributaries downstream from Project dams, have bolstered modeling capabilities in the basin. This work has developed spatially continuous water depth and velocity data in more than 250 kilometers $(\mathrm{km})$ of river downstream from Project dams and has predictive capability throughout the year at flows up to normal peak levels. Additionally, other methods are described for estimating habitat availability, which include habitat suitability criteria, logistic regression, occupancy and abundance modeling, and energetic based approaches. There are strengths and weaknesses to each approach and selection of the preferred approach in the Willamette River Basin will depend on the desired metrics of interest and the risk tolerance of managers and stakeholders in the basin.

\section{Introduction}

Upper Willamette River (UWR) spring Chinook salmon (Oncorhynchus tshawytscha) and winter steelhead (O. mykiss) are anadromous fish species that use the UWR and its tributaries to spawn, rear, and migrate to and from the ocean. However, the physical and ecological conditions on which these species depend have been substantially impacted by the construction and operation of the U.S. Army Corps of Engineers (USACE) Willamette Project, a system of 13 dams, reservoirs, and revetments that provide flood control and other societal benefits to communities in the Willamette Valley (fig. 1). By blocking fish passage and altering downstream hydrographs, thermal regimes, and habitat-forming processes, dams and reservoirs in the Middle Fork Willamette River, McKenzie River, and Santiam River Basins have contributed to habitat losses and constrained the ability of anadromous fish species to move between critical spawning and rearing habitats (National Marine Fisheries Service, 2008; Keefer and others, 2013; Wallick and others, 2013; Beeman and others, 2014; Kock and others, 2015). In consequence, UWR spring Chinook salmon and winter steelhead are listed as threatened under the U.S. Endangered Species Act (ESA; National Marine Fisheries Service, 1999a, 1999b).

In response to this listing, the National Marine Fisheries Service (now National Oceanic and Atmospheric Administration Fisheries) issued a 2008 Biological Opinion (BiOp; National Marine Fisheries Service, 2008), which concluded that continued operation of Willamette Project dams would jeopardize UWR spring Chinook salmon and winter steelhead, along with 11 other fish species, and specified several actions to improve flow and temperature management for listed species. These actions included improving upstream 


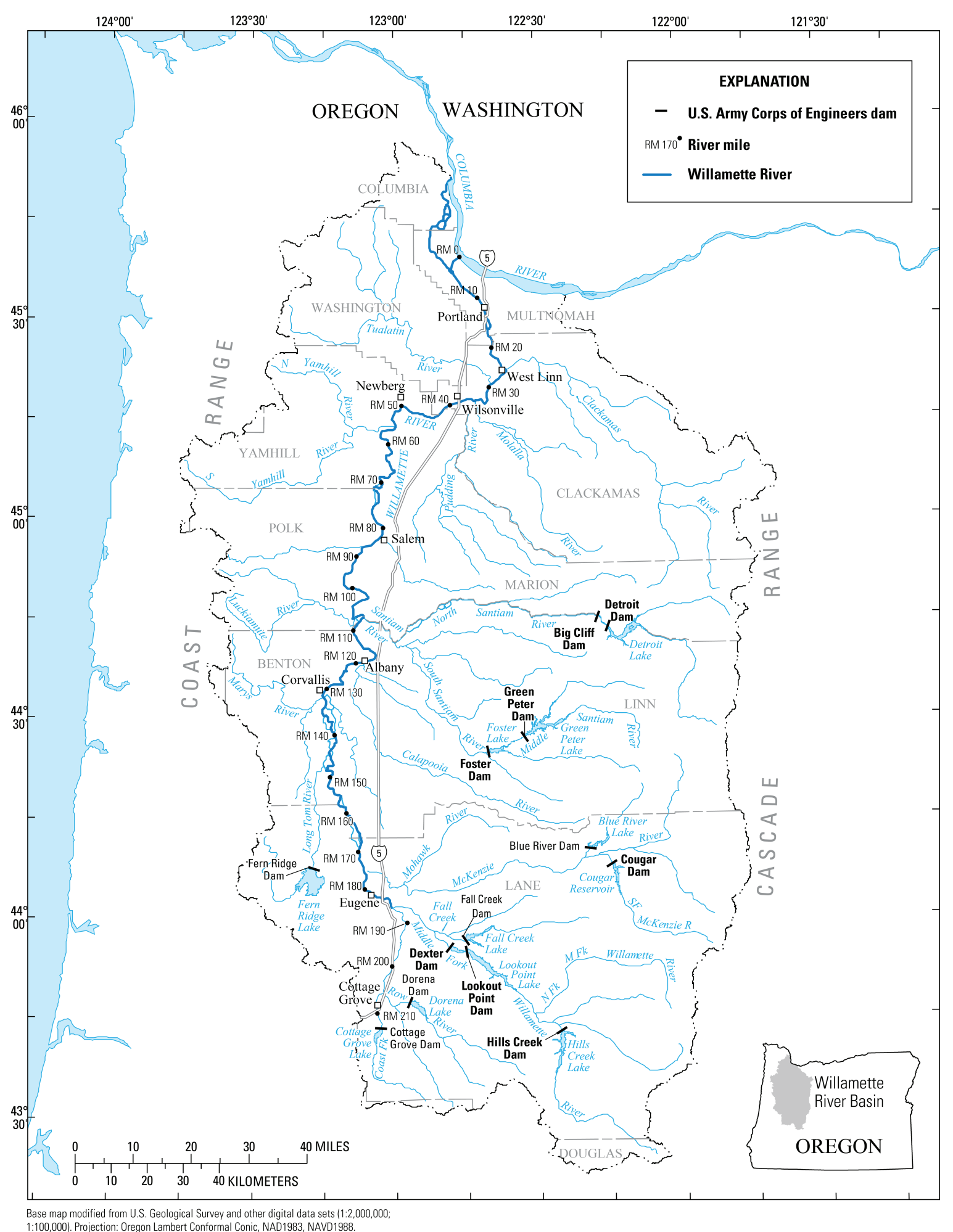

Figure 1. Willamette River Basin in western Oregon, highlighting the river network and locations of Willamette Project dams operated by the U.S. Army Corps of Engineers. 
and downstream fish passage at dams, specified minimum and maximum flow levels downstream from dams, specified ramping rates of managed flows, and special actions such as pulsed flows designed to benefit outmigration of juvenile fish. In addition, the BiOP mandated flow-related research, monitoring, and evaluation in rivers affected by Willamette Project dams to determine both compliance and effectiveness (National Marine Fisheries Service, 2008). In response to the $2008 \mathrm{BiOp}$ findings and previous consultations, the USACE established and implemented plans for improving fish passage and downstream conditions at several dams in the Willamette Project, including providing temperature control at Cougar Dam on the South Fork McKenzie River, fish passage at Foster Dam on the South Santiam River, seasonal downstream fish passage at Fall Creek Dam on Fall Creek, planned temperature control at Detroit Dam on the North Santiam River, and planned fish passage at Cougar and Detroit Dams. Research is underway to evaluate the feasibility of providing safe and effective fish passage for Lookout Point and Dexter Dams, which includes investigating water-management effects on habitat conditions downstream from these dams to support migrating UWR spring Chinook salmon and winter steelhead.

With multiple flow management, temperature control, and fish passage projects underway or already completed, the USACE is working to address effects of the Willamette Project dams on ESA-listed species and the $2008 \mathrm{BiOp}$ requirements. In support of this mission, the USACE and its regional partners need to better understand how operations at a project-wide scale influence the amount of habitat available for spawning adult and rearing juvenile Chinook salmon and steelhead. This information is needed to inform questions about dam operations to support fish passage goals, including trade-offs between passing fry downstream from dams to rear or encouraging reservoir rearing. Information about density dependence is also needed. Density dependent processes can arise as a function of fish passage management activities, population abundance, and hatchery supplementation, and will be directly influenced by the carrying capacity of the Willamette River and its major tributaries downstream from Willamette Project dams.

This study was conducted to address three primary objectives with the goal of providing information that could be used to inform flow-management decisions aimed at improving conditions for Chinook salmon and steelhead in the Willamette River Basin. These objectives include (1) reviewing existing habitat and fisheries datasets from the Willamette River to determine if these resources are useful for future analyses of flow-management scenarios in the basin and to identify key data gaps; (2) summarizing standard and alternative methods for estimating habitat availability under different flow- and temperature-management scenarios; and (3) identifying optimal methods for estimating carrying capacity under various scenarios with consideration of the potential for densitydependent effects. 


\section{Objective 1-Review Existing Willamette River Datasets and Identify Key Data Gaps}

\section{Existing Studies and Datasets}

We acquired and reviewed 10 studies and datasets from previous research in the Willamette River Basin (table 1) to understand what information was available, and to determine the extent to which they were useful for future analysis of flow management effects on salmonid habitat in the basin. With multiple flow management, temperature control, and fish passage projects underway or already completed, the USACE is working to address effects of the Willamette Project dams on ESA-listed species and the National Marine Fisheries Service $2008 \mathrm{BiOp}$ requirements. The USACE and its regional partners require tools that provide a better understanding of how operations at a Project-wide scale influence habitat availability and carrying capacity in the mainstem Willamette River and its major tributaries downstream from Project dams. To accomplish this, the USACE is interested in developing a model that will provide spatially explicit time-series estimates of useable habitat area under various flow-management scenarios. This model has been developed for most of the mainstem Willamette River (river kilometer [rkm] 81-282; White and others, 2020) and data collection is underway to inform model expansion to include major Willamette River tributaries. In addition to these efforts, a thorough review of existing studies and datasets from the Willamette River is necessary to determine if model expansion could benefit from these sources. We conducted this review to consider several factors, including (1) the spatial extent of the study area, (2) methods used, and (3) relevancy of results to flow management downstream from Project dams. We reviewed existing literature and datasets in the context of the specific goals of the USACE to develop spatially explicit time series of fish habitat and capacity.

Each of the habitat modeling studies (R2 Resource Consultants, Inc., 2005, 2009, 2014; Ellis Ecological Services, Inc., and Santiam Water Control District, 2010; River Design Group, Inc., and HDR, Inc., 2015; Bond and others, 2017) contained useful findings that contributed to the current state-of-knowledge on anadromous fish, and the habitat that they use in the basin. However, we concluded that the information available in each study was of limited use for future analysis of flow management in the Willamette River Basin for various reasons. For example, some of the studies (R2 Resource Consultants, Inc., 2005, 2009; Bond and others, 2017) were primarily focused on river and reservoir reaches located upstream from Project dams. Other studies conducted downstream from Project dams focused on specific habitat types (Stan Gregory, oral commun., June 2020; Williams, 2014; Whitman and others, 2017) and did not provide data that adequately represented all available habitat that would be required to understand the effects of flow management on habitat availability in the basin. The remaining studies (Ellis Ecological Services, Inc., and Santiam Water Control District, 2010; R2 Resource Consultants, Inc., 2014; River Design Group, Inc., and HDR, Inc., 2015) used habitat suitability approaches to estimate habitat availability but were conducted at spatial scales that may limit their usefulness in future, basinwide, modeling efforts. One analysis that could provide substantial insights into further evaluation of these studies would be to compare habitat predictions obtained from the model from White and others (2020) to predictions from these other studies to assess for differences, and to understand factors influencing these differences. This approach would provide a rigorous method for assessing the strengths and weaknesses of each study in a quantitative manner that was beyond the scope of this study.

The 2005 study by R2 Resource Consultants, Inc. (hereinafter R2; R2 Resource Consultants, Inc., 2005) was conducted to review stream survey data collected by the Oregon Department of Fish and Wildlife and U.S. Forest Service during 1989-2001. The goal of the review was to assess available data to determine if habitat availability could be estimated for Chinook salmon, steelhead, and bull trout in adult holding, spawning, and juvenile rearing life stages in the Santiam, McKenzie, and Middle Fork Willamette River Basins. In their assessment, R2 concluded that existing data were "generally outdated, collected with inconsistent protocols, or were missing critical stream sections, and thus, could not be used to assess mainstem habitats" (R2 Resource Consultants, Inc., 2009, page vi). This finding prompted the USACE to fund a second phase of research, which included additional data collection efforts during 2006 and 2007 (R2 Resource Consultants, Inc., 2009). For this effort, $414 \mathrm{~km}$ (257 miles) of stream habitat were surveyed with the majority ( 76 percent) of the habitat located upstream from Project dams, but habitat surveys included mainstem tributary habitat downstream from dams in the North Santiam, South Santiam, South Fork McKenzie, and Middle Fork Willamette Rivers (R2 Resource Consultants, Inc., 2009). The 2009 R2 study used these data, collected during fall 2006 and 2007, to provide estimates of habitat availability types for steelhead and Chinook salmon in major tributaries of the Willamette River. These studies provided useful information for resource managers in the Willamette River by reviewing existing datasets and estimating how adult holding and spawning habitat and juvenile rearing habitat are distributed upstream and downstream from Project dams in the Willamette River Basin.

In 2009, Ellis Ecological Services, Inc., and Santiam Water Control District (2010) conducted a study to evaluate how water withdrawals for a proposed hydroelectric facility would affect habitat availability for several fish species, including Chinook salmon and steelhead. This study was conducted in a 3-mile reach of the North Santiam River near Stayton, Oregon (Ellis Ecological Services, Inc., and Santiam Water Control District, 2010) and used the Instream Flow Incremental Methodology (IFIM; Bovee and others, 1998). 
Table 1. Summary of previous studies conducted in the Willamette River Basin that were reviewed to determine if data and results could be used in future assessment of habitat availability in the basin.

[NMFS, National Marine Fisheries Service; ODFW, Oregon Department of Fish and Wildlife; PHABSIM, Physical Habitat Simulation System; RHABSIM, River Habitat Simulation System; USFS, U.S. Forest Service; UWR, Upper Willamette River]

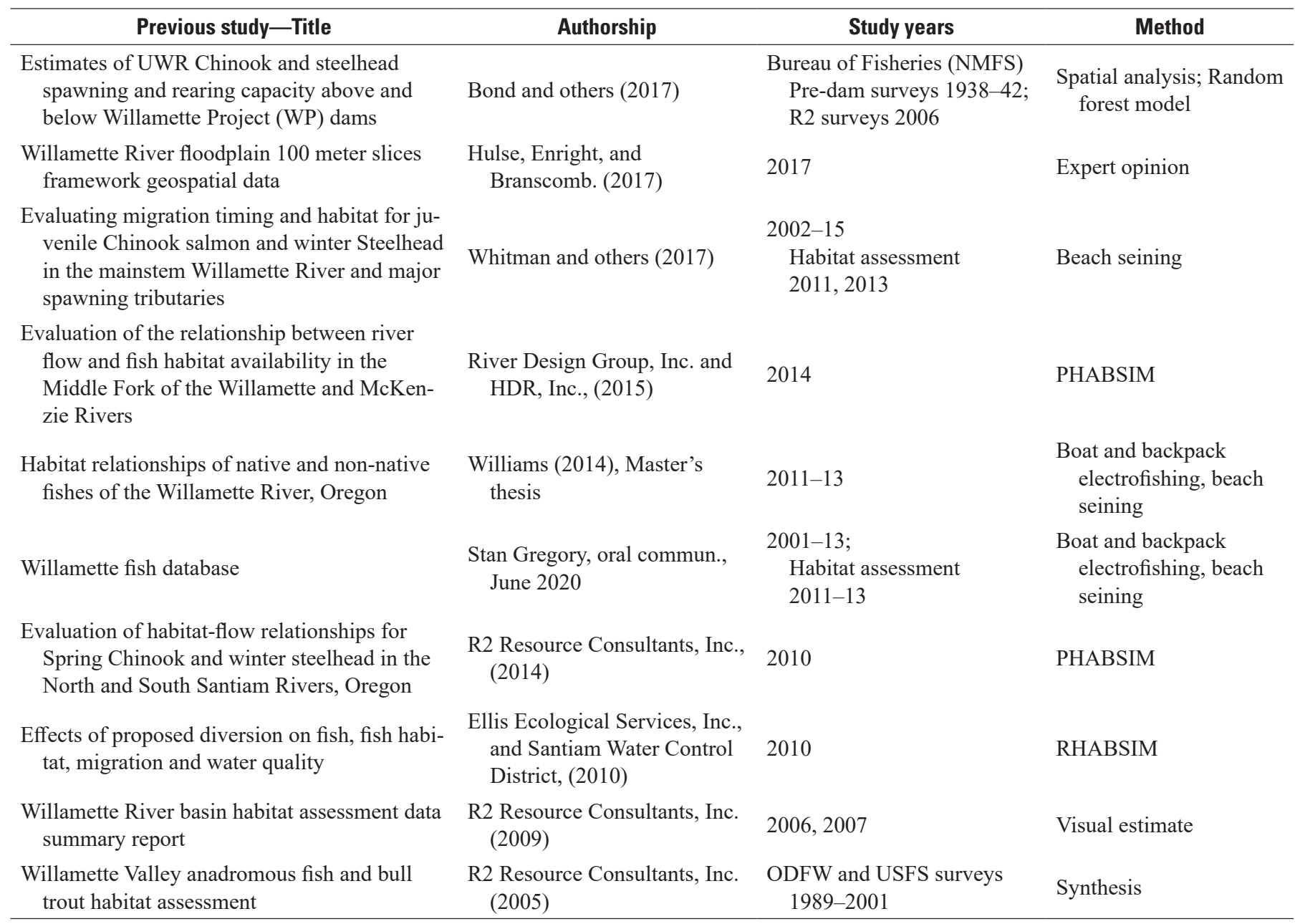

This study provided results that could be potentially insightful for flow management related to operations at Detroit and Big Cliff Dams in a short river reach. However, the information contained in the study was deemed to be too limited for future analyses due to the small size of the study area.

In 2010, R2 conducted a study to assess how different flow conditions affected habitat availability for juvenile and adult Chinook salmon and winter steelhead in the North and South Santiam Rivers (R2 Resource Consultants, Inc., 2014). This study was a substantial undertaking that included field data collection and habitat modeling using the Physical Habitat Simulation System (PHABSIM), which was also used for other modeling efforts in the basin (table 1). Habitat data were collected from a series of transects that provided a coarse characterization of reach-specific habitat features. Habitat suitability curves were developed for the North and South Santiam Rivers using information from the literature and local expertise, and habitat estimates were generated for reaches downstream from Big Cliff Dam (North Santiam River) and Foster Dam (South Santiam River; R2 Resource Consultants, Inc., 2014). The study produced useful results that showed how habitat availability was influenced by various flow levels in each river. Although this study achieved its stated goals, the results were confined to the Santiam River Basin, habitat suitability curves were generated using literature-based data, and habitat was coarsely characterized using data collected from river transects in specific reaches.

The River Design Group, Inc., and HDR, Inc. conducted a study in 2015 to assess the relation between river flow and spawning and incubation habitat for adult spring Chinook salmon downstream from Project dams in the Middle Fork Willamette River, South Fork McKenzie River, and McKenzie River (River Design Group, Inc., and HDR, Inc., 2015). This study included data collection efforts to describe habitat 
conditions at 10 transects within each study reach, providing information about channel bathymetry, water-surface elevations, velocity profiles, and substrate and channel cover types across a range of flow conditions that occurred in each tributary during September-January 2010 through 2015. This study provided useful information about how flow management influences habitat availability for adult spring Chinook salmon downstream from project dams.

The Bond and others (2017) study has three sections that focus specifically on (1) estimating spawning capacity for adult spring Chinook salmon upstream and downstream from Project dams, (2) estimating rearing capacity for subyearling Chinook salmon in Detroit, Foster, and Cougar Reservoirs, and (3) estimating summer parr rearing capacity for Chinook salmon and steelhead upstream and downstream from Project dams on the North Santiam, South Santiam, McKenzie, and Middle Fork Willamette Rivers. This study represents a substantial body of work, much of which is focused on areas upstream from Project dams. The first section of the report describes an effort to estimate spawning capacity of adult spring Chinook salmon in the North Santiam, South Santiam, McKenzie, and Middle Fork Willamette Rivers. This effort combines a geomorphic approach with pre-dam spawning substrate data (McIntosh and others, 1990) to generate spawner capacity in each basin. These estimates were then compared to estimates from R2 Resource Consultants, Inc. (2014). The second section describes a bioenergetics assessment of rearing capacity of subyearling Chinook salmon in Detroit, Foster, and Cougar Reservoirs. Consumption was simulated for resident and anadromous planktivores and compared to zooplankton density data from each reservoir to estimate the number of each species that could be supported in the reservoir. The third section of the report assessed summer parr rearing capacity for Chinook salmon upstream and downstream from dams on the North Santiam, South Santiam, McKenzie, and Middle Fork Willamette Rivers. Although this study provided information about capacity estimates for various life stages of Chinook salmon in the Willamette River Basin, much of the focus was on areas located upstream from Project dams so this study has little to offer future evaluations on decisions related to flow management. Furthermore, the USACE's primary interest is understanding how within-year water management and flow variability affects time-varying habitat availability and capacity. In contrast, the estimates of habitat capacity provided in Bond and others (2017) represent a static system-wide average of capacity. Therefore, although useful, the estimates and findings from Bond and others (2017) cannot be incorporated directly into habitat models for fine-scale temporally varying estimates of habitat availability.
We reviewed one sampling framework, one multiyear dataset, and two studies that could be particularly useful for future evaluations in the Willamette River Basin. The first of these is the SLICES framework (Hulse and Gregory, 2004), which was developed for community monitoring and site selection on the mainstem Willamette River and consists of $3001-\mathrm{km}$ sections on the mainstem river (Williams, 2014). This framework allows researchers to work and communicate on a common sampling platform within the basin, and to visually assess river features (relative width, presence of sloughs or backwater areas) within each slice using images available on the website (https://ir.library.oregonstate.edu/concern/ datasets/5712mc568; fig. 2). The second is the Willamette Fish Database, which is a collection of fish sampling data from Oregon State University and the Oregon Department of Fish and Wildlife from the mainstem Willamette River during 2001-2013 (Stan Gregory, oral commun., June 2020). This is a comprehensive dataset from 167 sites (96 mainstem and 71 slough) on the Willamette River, which includes native and non-native fish species. In addition to the fish sampling data, habitat data for each sampling site are also available for sampling that occurred in 2011, 2012, and 2013. The first of the two studies (Williams, 2014) included data collection during the summers 2011-13. Approximately 80,000 fish were collected during this study in the lower $280 \mathrm{rkm}$ of the Willamette River and its seasonally inundated floodplain. Results from the study provide a solid understanding of how native and non-native fish species are distributed in the river and provide information about important habitat types for various fish species. Finally, Whitman and others (2017) summarize rearing and migration timing data for juvenile Chinook salmon in the Willamette River and its major spawning tributaries collected during a long-term (2002-15) beach seine survey. Habitat relations were also assessed for two of the sampling years along with results from incidental sampling of juvenile steelhead. Collectively, these products comprise an important body of information related to juvenile salmon and steelhead behavior in the Willamette River Basin.

In summary, we found that existing datasets and studies from the Willamette River were useful contributions to the existing state-of-knowledge in the basin. However, these studies were not designed with the objective of developing spatially explicit time-series estimates of habitat availability or capacity in the mainstem Willamette River and major tributaries. Therefore, findings from these studies are at incongruent temporal or spatial scales for use in detailed habitat modeling aimed at achieving this objective in the future. 


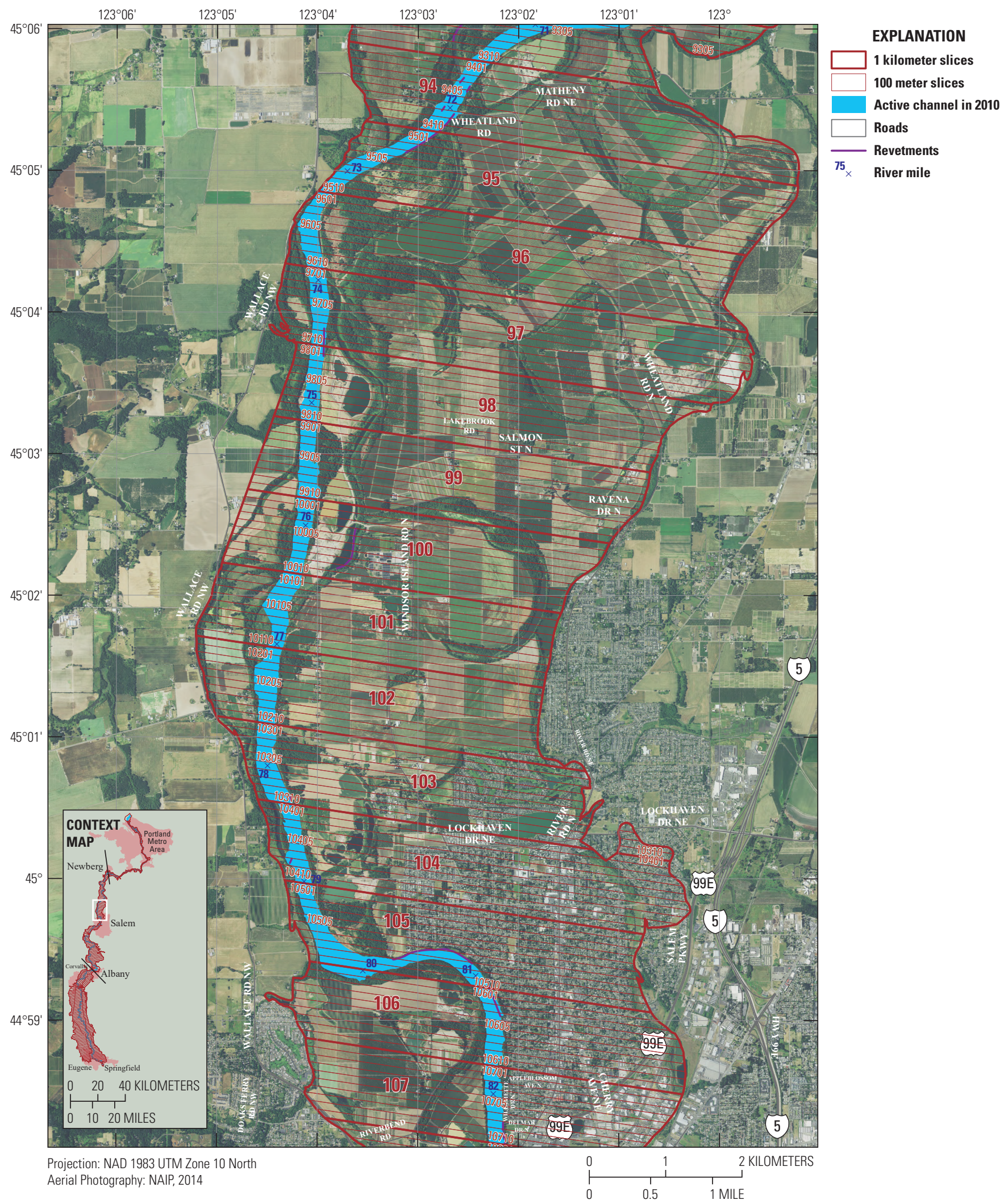

Figure 2. Example of the SLICES framework from the mainstem Willamette River Basin (https://ir.library.oregonstate.edu/concern/ datasets/5712mc568). 


\section{Objective 2-Summarize Methods to Estimate Habitat Availability}

The U.S. Geological Survey (Oregon Water Science Center, Portland, Oregon) has recently been working to develop a two-dimensional (2D) hydrodynamic model that can be used to describe how flow-management scenarios influence aquatic habitats downstream from Project dams (for example, Tiffan and others, 2002; Hatten and others, 2009). The original 2D model was constructed for the mainstem Willamette River in the reach between $\mathrm{rkm} 81$ and $\mathrm{rkm} 282$ with future data collection planned to allow expansion to the North Santiam, South Santiam, and Santiam Rivers, and a portion of the McKenzie River, downstream of Project dams. Once completed, the 2D model will cover most of the important anadromous salmonid habitat influenced by flow management at Project dams. The 2D hydrodynamic model will eventually be linked with water temperature and smallmouth bass habitat models to increase the predictive capability of the model by including these factors.

In preparing our summary of the available methodologies for quantifying salmonid habitat, our frame of reference was formed by the intended use of the 2D hydrodynamic model to estimate habitat availability in the Willamette River and major tributaries downstream from Willamette Project dams as a time-series (that is, dynamic hydrograph) function of riverflow and water temperature. Two-dimensional hydrodynamic models are spatially explicit numerical models comprised of georeferenced cells that contain estimates of water depth, depth-averaged velocities, Froude number, etc. (see Tiffan and others, 2002; Hatten and others, 2009). The challenge of quantifying habitat suitability centers on defining a mathematical function that takes cell-specific physical attributes as inputs and converts them to a numeric value measuring relative habitat suitability:

$$
\pi_{i}=f\left(\mathrm{x}_{i}\right)
$$

where

$\pi_{i} \quad$ is the relative suitability of cell $i$,

$\mathrm{x}_{i} \quad$ is a vector of habitat attributes measured at cell $i$ (for example, depth, velocity, substrate, cover, etc.), and

$f\left(\mathrm{x}_{i}\right) \quad$ is the function producing $\pi_{i}$ from $\mathrm{x}_{i}$.

This section summarizes the different methods used to define the habitat function $f\left(\mathrm{x}_{i}\right)$.

We use the term "suitability" in a generic sense and emphasize that it should not be confused with specific applications such as "habitat suitability criteria." Different methods for defining $f\left(\mathrm{x}_{i}\right)$ yield different biological interpretations about the meaning of $\pi_{i}$ that are important to consider when weighing the strength of inference associated with each method. In addition, although our frame of reference involves application of $f\left(\mathrm{x}_{i}\right)$ to two-dimensional hydrodynamic models, much of what follows applies to coarser level physical models such as one-dimensional PHABSIM models that characterize physical habitat across multiple channel cross sections (Bovee, 1982; Gard, 2005).

Methods for modeling habitat availability and use have evolved substantially during the past four decades (Som and others, 2016; Yi and others, 2017). Early approaches commonly used PHABSIM with habitat suitability indices derived using expert opinion (Bovee, 1982; Shirvell, 1989; Booker and Dunbar, 2004). As the science evolved, new methods were developed to describe the probability of habitat use by aquatic organisms in specific habitats (resource selection functions; Manly and others, 1992; Boyce and McDonald, 1999), to predict the probability of true presence and absence in habitats by accounting for imperfect detection probabilities (occupancy modeling; Wenger and others, 2008; Falke and others, 2012), and eventually incorporating factors such as food availability and energy expenditure (energetic approaches; Wall and others, 2016; Naman and others, 2019) into models that assess habitat use. As these methods evolved, advancements shifted from using expert opinion to develop $f\left(\mathrm{x}_{i}\right)$, which required no field data (for example, PHABSIM) to fitting statistical models to habitat use and physical data collected from the system of interest (presence/absence studies) to develop models that account for physical and biological (for example, food supply) factors in the suitability of a particular cell (for example, net rate of energetic intake). Thus, we describe habitat suitability methods along a gradient of increasing data requirements and describe the benefits, criticisms, and drawbacks of each method (fig. 3). This section is not intended to be an exhaustive review of the literature, but rather a description of the range of methods available for developing the habitat suitability function $f\left(\mathrm{x}_{i}\right)$ for the Willamette River.

Nearly all methods summarized herein measure habitat suitability on a relative scale from zero to one, with zero being interpreted as a particular cell being unsuitable habitat and one being interpreted as perfectly suitable. This quantity itself is useful in a spatially explicit context, as maps of habitat suitability provide useful insights into how habitat is spatially distributed laterally and longitudinally along the riverscape (Tiffan and others, 2002). Managers are also interested in the quantity of suitable habitat at a given flow summarized over some meaningful management unit such as a geomorphic habitat unit (for example, pool, riffle, run) or longitudinal unit (for example, per kilometer). Quantifying the amount of suitable habitat involves considering both habitat suitability and the aerial dimensions over which the suitability applies:

$$
H=\sum_{i=1}^{n \text { cells }} \pi_{i} a_{i}
$$

where

$H \quad$ is the amount of suitable habitat (typically square meters or hectares),

$a_{i} \quad$ is the area of cell $i$ (typically square meters), and

$n \_$cells is the number of cells contained within the unit's boundaries. 
This equation highlights how intermediate values of suitability contribute to the total habitat area. Mathematically, $\pi_{i}$ is the fraction of cell area $a_{i}$ contributing to the total amount of habitat. Statistically, for methods where $\pi_{i}$ can be interpreted as a probability that a cell is occupied by one or more individuals, $H$ can be thought of as the expected value (that is, the mean) of the amount of suitable habitat. For PHABSIM and methods using habitat suitability criteria (HSC; Thomas and Bovee, 1993; Baker and Coon, 1997), $H$ is equivalent to the metric known as weighted useable area. Habitat area may also be summarized over particular ranges of $\pi_{i}$ by defining break points that characterize poor-, average-, and high-quality habitat (for example, summing over the ranges of $\pi_{i}=0-0.33$, $0.33-0.66$, and $0.66-1$, respectively). At the extreme of this approach, a single cutpoint of $\pi_{i}$ may be defined, above or below which the cell is considered as suitable or unsuitable habitat.

\section{Habitat Suitability Criteria}

HSC methods cover an extremely wide class of approaches for constructing $f\left(\mathrm{X}_{i}\right)$, ranging from expert opinion (Hatten and others, 2014) and literature-based approaches (DeWeber and Peterson, 2020) to statistically rigorous approaches for fitting habitat suitability models to field data (Som and others, 2016; Hatten and others, 2018). The available literature on this topic is immense and includes the field of IFIM and the PHABSIM habitat modeling platform. Common among the various HSC approaches, however, is the procedure for constructing $f\left(\mathrm{x}_{i}\right)$, which involves
(1) developing a univariate habitat suitability index (HSI) for each physical variable (for example, depth and velocity), and

(2) a function that combines the univariate HSIs (that is, $f\left(\mathrm{x}_{i}\right)$ ) into a composite suitability index (CSI; that is, $\pi_{i}$ ).

Each univariate HSI assigns a value between zero and one for a particular value of the physical variable. The composite suitability index defines a function that combines the univariate HSIs into one CSI on a $(0,1)$ scale. Standard functions include (1) the product of univariate HSIs, (2) the geometric mean of univariate HSIs, or (3) the minimum value of the univariate HSIs (Wakeley, 1988; Brooks, 1997).

Next, we provide two examples illustrating the range of methods used for generating a composite suitability index. First, the SWIFT team (Science of the Willamette Instream Flows Team) used a literature review to identify three ranges of acceptable conditions for juvenile Chinook salmon (narrow, median, and broad, DeWeber and Peterson, 2020). For habitat modeling purposes under each category, SWIFT criteria consider a cell as suitable habitat only if the values of all physical variables fall within the defined range. These criteria can be expressed as univariate HSIs with the composite suitability index being the product of univariate HSIs (fig. 4). Values outside the prescribed range are assigned an HSI of zero and values within the range are assigned an HSI of one. Next, for a particular hydraulic model cell at a given flow, taking the product of the three HSI values for the CSI is equivalent to the rule that all three variables must fall within the prescribed range for each physical variable. That is, if any of the HSI values equals zero, then the CSI will be zero.

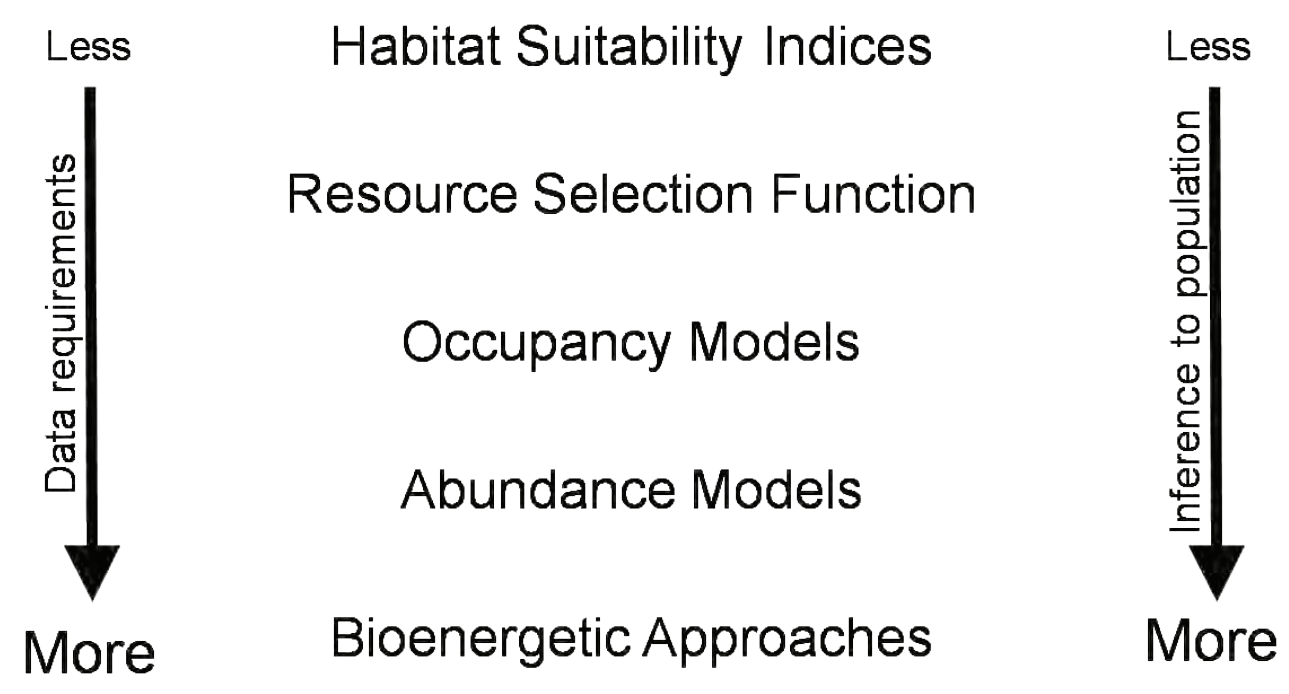

Figure 3. Conceptual hierarchy of five contemporary habitat assessment methods ranging from less complex (top) to more complex (bottom), including relative data requirements and the relative inference of each approach to a given population. 

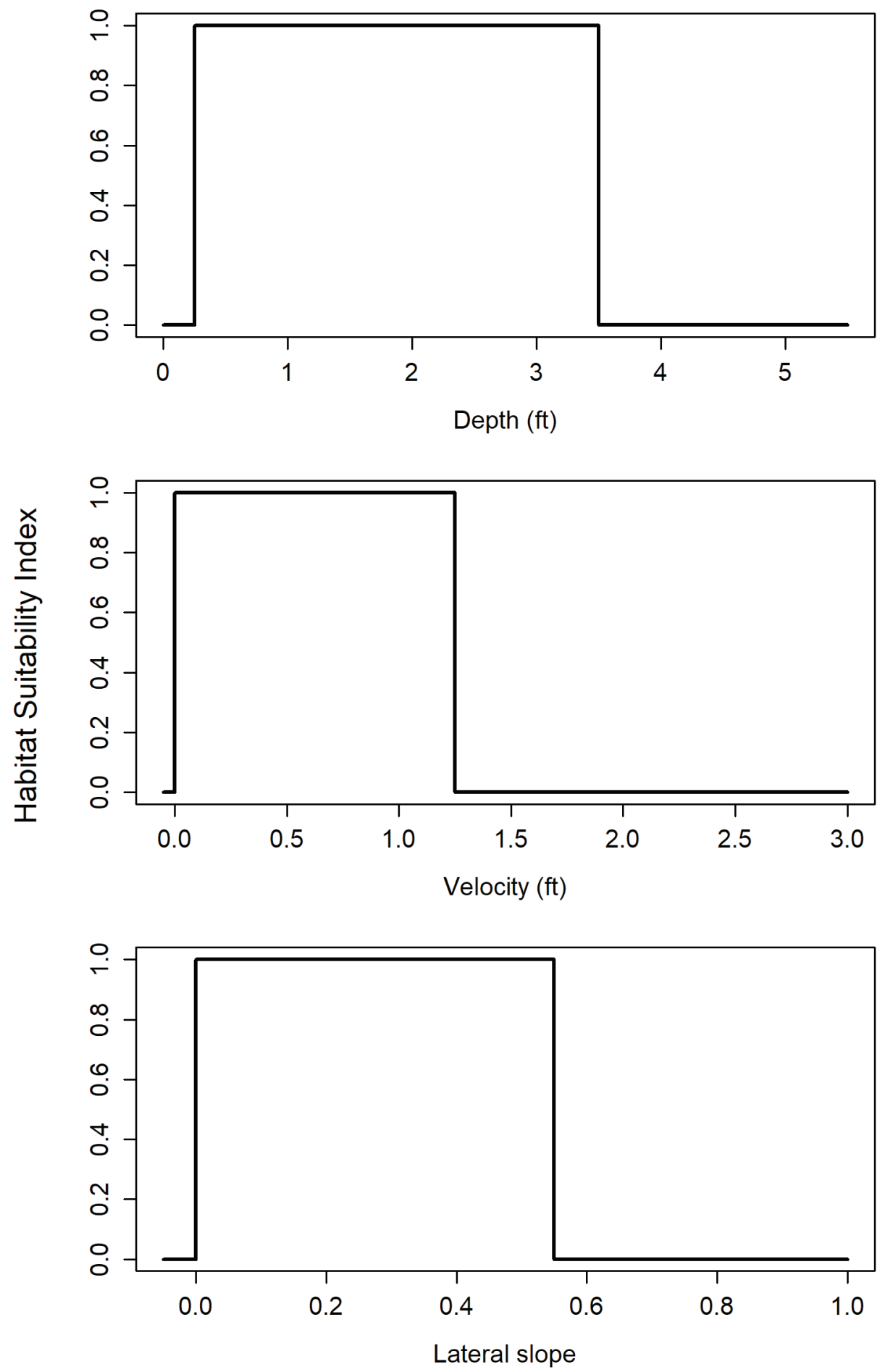

Figure 4. Science of the Willamette Instream Flows Team habitat criteria represented as univariate Habitat Suitability Indices for the median category for Chinook salmon fry (based on table 1 in DeWeber and Peterson, 2020). [ft, foot.] 
For the second example, HSIs may be developed from habitat use data collected within the system of interest. Traditionally, habitat use data consist of what is referred to as "presence only" data where measurements of physical variables are taken at locations where fish are observed and known to be present. Given a dataset of sufficient sample size representing a range of physical variables at which fish were observed, analytical and statistical methods can be applied to the data. For example, one approach involves generating a histogram representing the frequency with which fish were observed at given values of the physical variables. More quantitative advancements to this approach rely on fitting non-parametric kernel density estimators to approximate the distribution of the data (Hayes and Jowett, 1994; Hatten and others, 2018). Recent methods involve statistically fitting probability distribution functions (PDFs) to the presence only data and then scaling the PDF to a maximum value of one (Som and others, 2016). For example, Perry and others (2019) used the methods of Som and others (2016) to generate HSIs for juvenile Chinook salmon in the Klamath River (fig. 5). Advantages to this approach include the ability to use model selection techniques for identifying the best-fit distribution and quantification of uncertainty in the estimate of HSC (but see also Williams, 2010). Despite advancements in methods for quantifying HSIs, a function for combining the HSIs into a CSI must be assumed.

IFIM, PHABSIM, and the underlying HSCs on which they rely have been criticized in several reviews over the years (Mathur and others, 1985; Orth, 1987; Gan and McMahon, 1990; Castleberry and others, 1996; Moir and others, 2005; Beecher and others, 2010; Lancaster and Downes, 2010; Railsback, 2016). A common criticism is that HSCs are developed using expert judgment or literature-derived inputs rather than data collected from the river of interest, and studies have shown that this approach can result in predictions that are inaccurate or biased (Conder and Annear, 1987; Gan and McMahon, 1990; Moir and others, 2005; Beecher and others, 2010). Other criticisms have questioned the scientific defensibility of PHABSIM studies because the number of transects used often do not adequately represent the river segment being modeled and uncertainty in model outputs is seldom addressed (Castleberry and others, 1996; Williams, 2001, 2010). Habitat studies on the Willamette River (R2 Resource Consultants, Inc., 2005, 2009; Bond and others, 2017, as examples) have largely relied on HSCs, which are based on expert opinion and out-of-basin fish use data as well, although the reliability of estimates produced from these efforts is unclear.

Other criticisms rest on the nature of presence-only data for inference and the sophistication of quantitative techniques used when generating and combining HSIs. First, presenceonly data contain no information about the physical variables where fish are absent, and therefore important information is missing about the probability of occurrence at a given location relative to the availability of different physical variables. Royle and others (2012) found that analytical techniques for presence-only data resulted in extreme under-prediction of species occurrence relative to logistic regression analysis that included habitat characteristics where species were both present and absent. Second, HSIs have also been criticized for lack of measures of uncertainty (for example, confidence intervals), although several methods have been developed (Williams, 2013; Som and others, 2016). Last, the functions for combining HSIs into a CSI are somewhat arbitrary and do not consider interactions among variables or non-linear responses of habitat selection to physical variables.

\section{Logistic Regression Models}

Whereas data analysis for HSIs rely on presence-only data, logistic regression models are applied to binary data; that is, data where fish are present at location $i\left(y_{i}=1\right)$ or notpresent at a location $i\left(y_{i}=0\right)$. This type of data is typically referred to as "presence/absence data." However, we use the terms "not present" or "non-presence data" to highlight the fact that zeros do not necessarily mean that fish are absent, as the term "presence/absence" implies. Rather, zeros are indicative of both false negatives (no fish detected at location $i$ but fish were present) and true negatives (no fish detected at site $i$ because fish were absent).

Logistic regression models applied to binary presence/ non-presence data may be further divided into two classes. First, resource selection functions often refer to logistic regression models applied to presence-only data that have been augmented with "pseudo-absences" using locations where animals may or may not have visited. This type of data is often referred to as use-availability data (Johnson and others, 2006). For example, Hatten and others (2013) developed a resource selection model for Moapa Dace (Moapa coriacea), a small thermophilic cyprinid inhabiting spring-fed tributary of the Muddy River, Nevada. Hatten and others (2013) developed a two-dimensional hydrodynamic model to quantify depth and velocity where Moapa Dace were observed by snorkelers. Then they generated pseudo-absences by randomly sampling cells from the hydrodynamic model where fish were not observed and analyzed these use-availability data using logistic regression.

Second, the more standard data type for logistic regression analysis occurs when sampling locations are pre-selected in some fashion (for example, stratified random sampling), sites visited, and then presence or non-presence recorded for each site. For example, Tiffan and others (2006) applied logistic regression techniques to presence / non-presence data generated using point electrofishing sampling in the Hanford Reach of the Columbia River. They found that water velocities less than 45 centimeters per second and low lateral bank slopes were associated with a higher probability of presence. Alternatively, in situations where salmon create nests (redds) that are obvious to observers, pseudo-absences can be randomly generated in areas without redds after applying a GIS buffer (mask) around the red (see Hatten and others, 2009, 2018). 


\section{Fry}
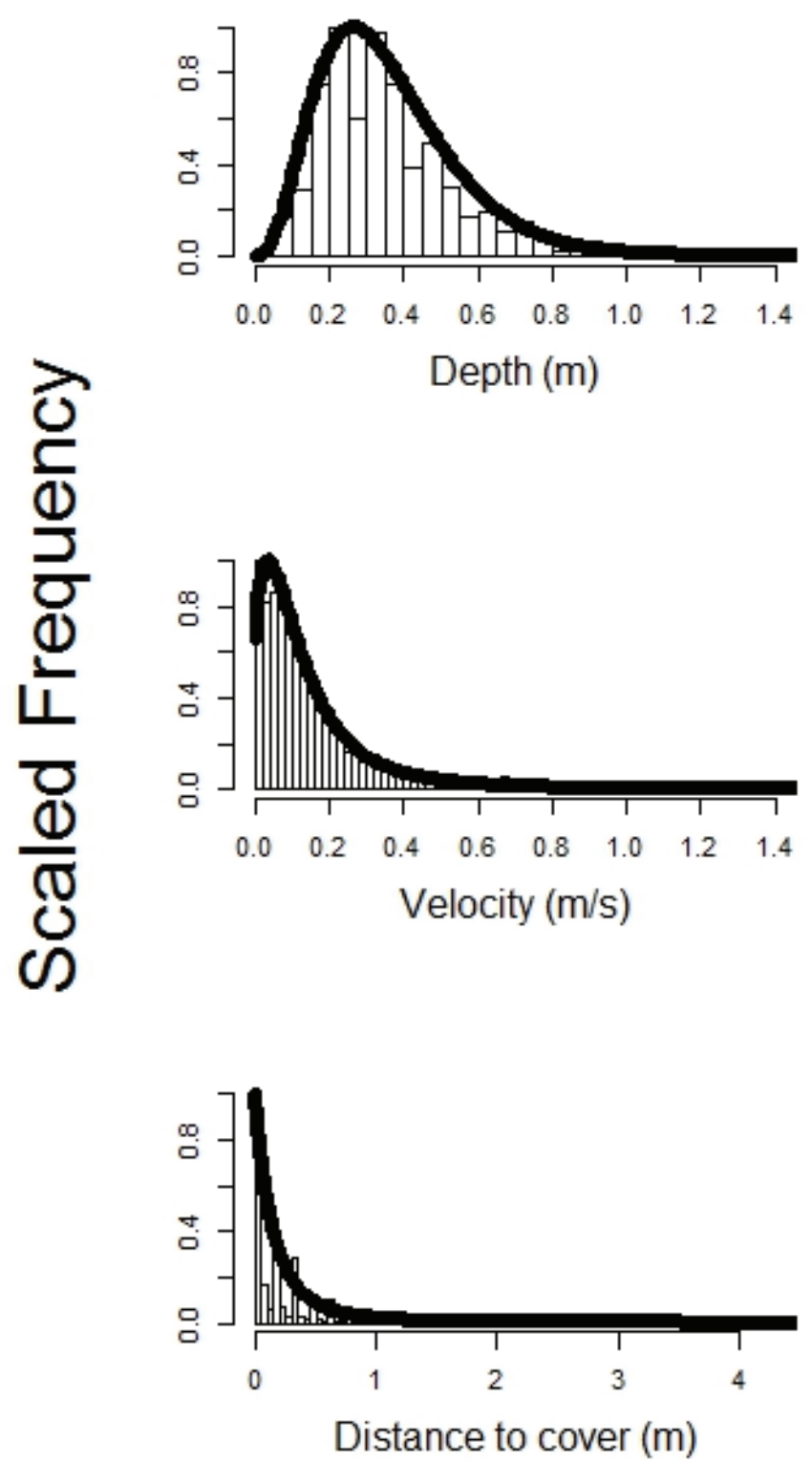

\section{Parr}
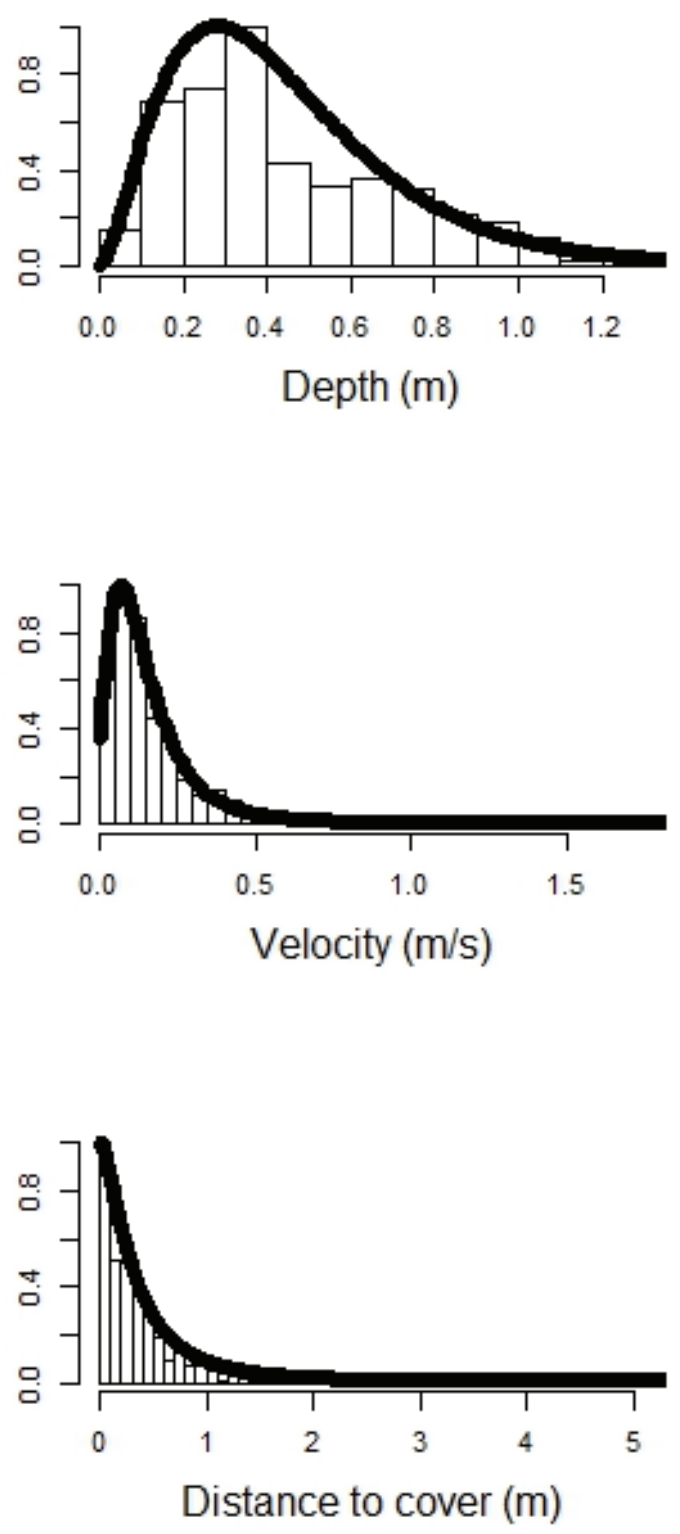

Figure 5. Univariate habitat suitability curves for depth (in meters [m]), velocity (in meters per second [m/s]), and distance to cover (in $\mathrm{m}$ ) fitted to presence-only observations of juvenile Chinook salmon fry and parr in the Klamath River, California, using methods of Som and others (2016). Figure reprinted from Perry and others (2019).

Logistic regression has several advantages over habitat suitability indices. First, the definition of the habitat suitability response variable, $\pi_{i}$, is clear and biologically interpretable: $\pi_{i}$ is the probability of fish being present at site $i$. In contrast, CSIs cannot be interpreted as a probability of presence but rather as a relative value of the suitability of site $i$. Second, because logistic regression has a well-founded statistical methodology, measures of uncertainty such as confidence intervals are standard output. Third, the data informs the regression coefficients, which allow different weighting of the relative contribution of each physical variable to the probability of presence (that is, the odds ratio). In contrast, the functions to combine HSI into a composite suitability index assume equal contribution of the physical variables to the composite suitability. Last, different hypotheses about the form of the $f\left(x_{i}\right)$, the logistic function expressing $\pi_{i}$ as a function of physical variables $x_{i}$, can be evaluated by comparing the goodness of fit of different model structures to the data. For example, models that include quadratic terms that capture optimal values of physical variables can be compared against models with 
only additive effects among physical variables (Hatten and others, 2009). Beakes and others (2014) evaluated statistical approaches to estimating salmon habitat where they compared a model-averaged logistic regression model to the more standard technique of combining univariate suitability indices. They found that the standard method of aggregating univariate suitability indices tended to over-predict habitat occupancy and under-predict model uncertainty.

One of the chief drawbacks of presence/non-presence data is the implicit assumption that zeros represent true absences. Imperfect detection, regardless of the sampling method (electrofishing, snorkeling, seining, etc.), is the rule rather than the exception. Consequently, false absences contaminate presence/non-presence data, leading to negative bias in the probability of presence. More importantly, if the detection process is also related to the physical variables hypothesized to influence habitat use (for example, fish detection by a snorkeler might decrease with increasing depth), then the estimated relation between physical variables and habitat use may be biased.

\section{Occupancy Models}

Occupancy models extend logistic regression models by explicitly estimating detection probability, thereby distinguishing between true absences and false absences (MacKenzie and others, 2002). Estimating detection probability requires additional data collection in the form of repeated independent sampling at site $i$. For example, if two snorkelers independently record whether fish are present at site $i$ and the resulting data are a 1 and a 0 , then we know that fish were present but not detected by one of the snorkelers. These data are formally incorporated into a statistical model allowing for the estimation of detection probability and occupancy probability. For example, Sethi and Benolkin (2013) used replicate minnow traps in an occupancy model design and estimated a mean probability of detection of 68 percent. Because the goal of their study was to document salmon-bearing water bodies, they were able to quantify the probability of a true absence even if no salmon were captured. Given an occupancy design with replicate site-level sampling, the probability of true presence can be modeled as a function of habitat covariates in a logistic regression framework, similar to standard presence/ non-presence data.

\section{Abundance Models}

Abundance is a fundamental quantity of interest in most fish and wildlife monitoring programs yet one of the most difficult parameters to estimate. Although statistical methods for estimating abundance form the subject of numerous textbooks (for example, Seber, 1982), most of these methods focus on estimating population sizes over large spatial and temporal scales and often rely on mark-recapture techniques. In contrast, in our application we are interested in drawing inference about the number of fish occupying a specific habitat patch on a spatial scale of the cells in hydrodynamic models used for habitat modeling (for example, less than 10 square meters). Furthermore, although occupancy probability can be interpreted as the probability of one or more individuals occupying the site, measuring abundance at the same site may provide more detailed information about the quality of the site as it relates to physical habitat variables.

Although many sampling methods can be used to obtain a count of individuals at a sampling location (snorkeling, electrofishing, minnow traps, seines), count-type data (for example, counts, count per unit effort, density) will typically underestimate the true abundance due to imperfect capture efficiency of sampling gears. Furthermore, although counttype data are often used as an index of abundance, as with presence/absence data, if habitat covariates affect both the detection process and the abundance process (for example, large woody debris), then inferences about habitat covariates may be biased. Another challenge to estimating abundance at small spatial and temporal scales is that mark-recapture techniques often cannot be used because fish may leave the sampling area (lack of geographic closure) or may be too small to effectively mark.

Much progress has been made over the last 15 years in the development of statistical models that are able to estimate abundance using spatially replicated count data. This wide class of models was first developed by Royle (2004) and are known as $N$-mixture models. The data for the basic $N$-mixture model follows similarly to that in occupancy models where replicate independent counts of individuals are obtained at a site when the site is deemed closed to immigration or emigration. Replicate counts at site $i$ are assumed to be drawn from some underlying true abundance, $N_{i}$, with detection probability $p$. Furthermore, by representing true abundance across multiple sites as a Poisson distribution with mean $\mu, N$-mixture models can estimate both abundance and detection probability. As with occupancy and logistic regression models, both detection probability and abundance (or density when scaling abundance to sampling area) can be modeled as functions of habitat covariates.

$\mathrm{N}$-mixture models have both strengths and weaknesses. The ability to estimate detection probability without having to mark individuals in any way is a major strength of this approach, but this comes at a cost of being "data hungry" in the sense that large sample sizes are required to precisely estimate parameters of interest. Other strengths include the flexibility of N-mixture models to accommodate overdispersion in abundance or to substitute different sampling models for specific sampling designs. For example, multi-pass depletion models where individuals are removed on successive samples (for example, using beach seines or electroshocking) can be substituted into the $N$-mixture framework to estimate detection probability (Dorazio and others, 2005). Last, $N$-mixture models may be difficult to fit to data or produce biased estimates of abundance in situations with small sample size, few replicate samples, and low detection probability (Barker and others, 2018). 
Recently, $\mathrm{N}$-mixture models were used to assess the relation between physical habitat variables and densities of juvenile Chinook salmon on the Trinity River, California (Som and others, 2018). This study used dual independent snorkelers to obtain independent counts of juvenile Chinook salmon within patches of relatively homogeneous habitat. The authors quantified the effect of depth, velocity, and distance to cover on abundance of juvenile Chinook salmon while accounting for the effect of imperfect detection. One of the key findings was that the effect of depth mitigated the effect of velocity on abundance, indicating a broader range of suitable habitat over the range of depth relative to the findings of many other studies. This study has formed the basis for the current field study being conducted in the Willamette Valley by the U.S. Geological Survey, Columbia River Research Laboratory. One of the advantages of this study design is that the data can also be used for occupancy modeling either by using $N$-mixture models to calculate the probability of absence $(N=0)$ or by simplifying the count data to presence/non-presence data.

\section{Energetic-Based Approaches}

Energetic-based approaches involve integrating a driftforaging model with physical variables (that is, depth and velocity) and food availability (that is, drift) to predict whether a foraging location is energetically profitable (Fausch, 1984; Hughes and Dill, 1990). These methods have been proposed as a more mechanistic underpinning for the drivers of habitat selection relative to models based solely on physical variables because they provide metrics more closely related to fitness (Naman and others, 2019). Net energy intake is the currency of drift foraging models measuring the difference between gross energy intake and energetic costs of occupying a particular foraging location (Rosenfeld and others, 2014). Inputs into the drift foraging model include measures of drift concentration, fish size, water temperature, and water velocity at a foraging location (Naman and others, 2019). At its simplest interpretation, negative net energy intake values indicate a foraging location that is unsuitable, whereas positive values indicate profitable, and therefore suitable, habitat. Outputs to drift foraging models may also be scaled to $0-1$ values similar to HSI or resource selection functions (Naman and others, 2019).

Energetic based approaches also have advantages and disadvantages. As mentioned above, this fitness-based approach models habitat suitability as arising from fundamental biological processes driving the need for individuals to grow and survive. In addition, this framework expands the ecological niche from depending on solely physical variables to integrating biological variables such as drift concentration and food availability. Furthermore, drift foraging models more naturally integrate water temperature into habitat selection models by calculating swimming costs of occupying a particular location. However, these models also require detailed information about drift concentration and can be computationally intensive requiring long model run times. Furthermore, most model applications have assumed constant or average drift concentrations across a range of flow (Rosenfeld and others, 2014). Yet recent work has revealed that drift concentration may change in response to flow, thus influencing the profitability of a foraging location relative to a constant drift assumption (Hayes and others, 2019). Although more work is needed to refine energetic modeling approaches, numerous papers have shown that energetic-based models can outperform physically based models (Hayes and others, 2016; Rosenfeld and others, 2016; Naman and others, 2019).

\section{Objective 3-Identify Optimal Methods for Estimating Carrying Capacity and its Influence on Density-Dependent Processes in the Willamette River and its Major Tributaries}

Carrying capacity and habitat availability are closely related but distinct concepts. Available habitat can be thought of as the quantity of wetted riverine habitat (typically surface area; for example, square meters or hectares) that has the appropriate biotic (for example, food) and abiotic (for example, water velocity, depth, temperature) attributes to support a particular life stage. In contrast, a common definition of capacity is the maximum abundance that a given unit of river can support over a period of time sufficient to complete a given life stage. In its simplest form, capacity $(K)$ is a function of habitat availability and the maximum fish density $(c)$ per unit of suitable habitat area $(A)$ according to the relationship $K=c$ $\times A$. Although the density of fish may in turn be a function of micro-habitat attributes (Som and others, 2018), this general conceptual model still applies. In turn, capacity can influence demographic processes through density-dependent survival, growth, or movement (Independent Scientific Advisory Board, 2015; Perry and others, 2018).

Density-dependent population models (for example, the Beverton-Holt stock-recruitment model) illustrate how density dependence manifests at population levels well below capacity (fig. 6). For example, density independence implies that survival is constant with respect to population abundance (fig. 6). However, under density-dependence, survival declines as population abundance approaches capacity fig. 6). Thus, density-dependence becomes apparent at population levels well below capacity (the point at which the dashed and thin solid lines in fig. 6 begin to diverge). This conceptual model illustrates how changing habitat area $(A)$ or influencing habitat attributes that affect maximum habitat density $(c)$ ultimately modifies total carrying capacity $(K)$, in turn affecting the population abundance at which density-dependence begins to be expressed. 
Every measure of carrying capacity is linked to some underlying spatial and temporal scale of measurement. At the broadest geographic scale, the size of a drainage basin influences the catchment area that receives precipitation, which affects stream order and magnitude of discharge, ultimately determining the available habitat area to support anadromous salmonid populations. For example, the capacity and equilibrium population parameters in stock recruitment models have been shown to be positively related to accessible drainage basin area (Parken and others, 2006; Liermann and others, 2010). This finding makes sense- larger drainage basins can support larger salmon populations, all else being equal. At the finest spatial scale, an individual's space requirements for successful feeding, growth, and survival dictate inter- and intra-specific competitive interactions that affect the number of individuals able to "fit" into a given unit of suitable habitat. For example, the seminal paper of Grant and Kramer (1990) showed that an individual's territory size was a significant predictor of the upper limit of population density for stream salmonids.

Estimates of capacity also represent characteristic at the temporal scale. Capacity estimates at the drainage basin scale encompass an entire life cycle, and thus the capacity timescale on the order of years for anadromous salmonids. Temporal scales for measures such as territory size or upper bounds of density based on visual surveys (for example, snorkeling) represent timescales much closer to instantaneous temporal

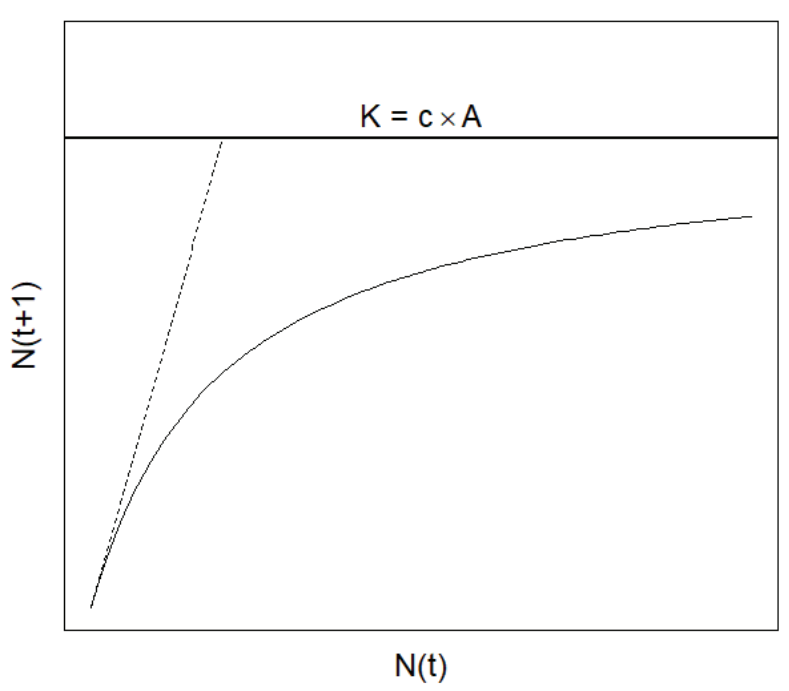

Figure 6. Beverton-Holt model showing the linkages between habitat area (A), maximum density per unit of suitable habitat area (c), carrying capacity ( $\mathrm{K}$, heavy solid line) and their influence on density-dependent population dynamics. The dotted line shows a density independent population model where survival is independent of the number of individuals at time $t, N(t)$. scales. That is, maximum density estimates based on visual surveys represent how many fish a given habitat can hold at a particular snapshot in time. It makes sense, then, that capacity estimates should decrease as the temporal scale of resolution increases. For example, a particular stream foraging location may be capable of supporting highly dense aggregations (for example, schooling) for short periods of time, but lower average densities over longer time frames for feeding rates to support growth.

Particular life stages represent spatiotemporal scales intermediate to drainage basin/lifecycle scales and territory/ instantaneous scales. For example, the fry life stage, bracketing the time from emergence until growth to some critical size threshold defining the parr stage, encompasses timescales on the order of weeks to months and spatially encompasses the array of habitats necessary for an individual to successfully complete this life stage. The multistage Beverton-Holt model put forth by Moussalli and Hilborn (1986) illustrates this concept by expressing cumulative capacity across multiple life stages as a function of stage-specific productivity (that is, survival) and capacity parameters:

$$
C_{n}=\frac{P_{n}}{\sum_{i=1}^{n} \frac{P_{i}}{c_{i}}}
$$

$$
\begin{gathered}
\text { where } \\
C_{n} \quad \begin{array}{r}
\text { is the cumulative capacity from lifestages } i \\
=1, \ldots, n,
\end{array} \\
P_{i} \quad \begin{array}{r}
\text { is the cumulative productivity representing } \\
\text { the product of stage-specific survival } \\
\text { probabilities from stage } 1, \ldots, i, \text { and }
\end{array} \\
c_{i} \quad \text { is the capacity of stage } i .
\end{gathered}
$$

This formulation illustrates how cumulative capacity through multiple lifestages is a function of both stage-specific capacities and survival probabilities. To illustrate the linkage between capacity and time, consider four life stages each with 3 -month stage durations, stage-specific capacities of 10,000 individuals, and constant survival rates leading to an annual survival of 25 percent. The cumulative capacity of this population decreases from 10,000 to 1,380 individuals over three successive 3-month periods (fig. 7).

Approaches for estimating carrying capacity have focused on opposite ends of the spatiotemporal scales. By far, spawner-recruit models (for example, the Beverton-Holt or Ricker model) have formed the basis of salmon population management, providing statistical estimates of carrying capacity at the population or management-unit level (Quinn and Deriso, 1999; Hilborn and Walters, 2013). In contrast, territory size measured for territorial juvenile salmonids provides an estimate of the per-individual space requirements at finer temporal scales. Between these extremes, multi-stage population models provide a means for linking finer scale spatiotemporal dynamics at the scale of life stages to population-level capacity. 


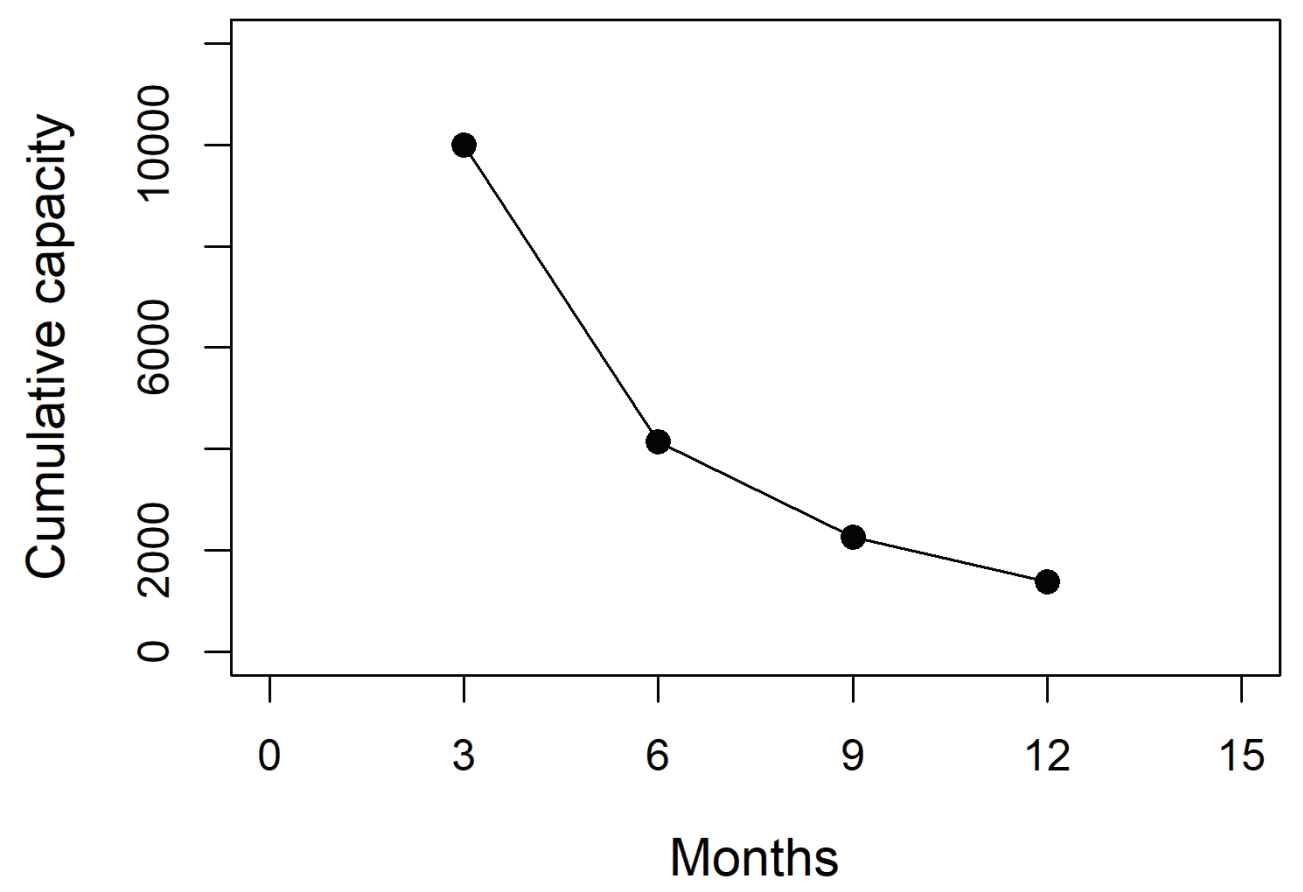

Figure 7. Hypothetical four-stage population illustrating the linkage between capacity and time.

At the population level, statistical models provide a means not only for estimating capacity, but for understanding effects of management actions or environmental variation on recruitment. For example, recent analysis by Scheurell (2019) estimated a carrying capacity of approximately 9,000 natural-origin Chinook salmon spawners in the Willamette River Basin. Scheurell (2019) also found the strong support for density dependent population dynamics and found the most support for the effect of maximum flow during the period when age- 2 smolts were outmigrating. Juvenile abundance data may also be used within multistage models to estimate capacity of different life stages. For example, using abundance estimates of naturally produced juvenile fall Chinook Salmon in the Snake River, Tiffan and Perry (2020) estimated a juvenile capacity of 1.25 million fish. Tiffan and Perry (2020) also found considerable support for density dependence as evidenced by little increase in juvenile recruitment as abundance of female spawners increased to greater than 10,000.

At the individual level, salmonids often maintain territories by defending profitable feeding areas. If the supply of profitable feeding areas is limited, then the availability of feeding areas can impose an upper limit on the number of fish the stream supports. As mentioned previously, Grant and Kramer (1990) found strong support for this theory by showing that an individual's territory size was a significant predictor of the upper limit of population density for stream salmonids. As further support for the link between territory size and carrying capacity, Ayllón and others (2012) estimated carrying capacity as the amount of available habitat divided by the expected individual territory area. They found that this model explained annual fluctuations in brown trout (Salmo trutta) across multiple years and populations.

Although a clear link exists between capacity and territoriality of resident stream salmonids, the degree to which juvenile anadromous salmonids exhibit territoriality can vary by life stage, life-history strategy, and environmental conditions. For example, Taylor (1990) found that parr of ocean-type (for example, fall run) juvenile Chinook salmon were more aggressive than fry, but both life stages were less aggressive than stream-type (for example, spring run) juvenile Chinook salmon. Furthermore, juvenile Chinook salmon can often be found in dense three-dimensional schooling aggregations. Neuswanger and others (2016) found that schooling juvenile Chinook salmon avoided proximity of their neighbors and maintained a distance of 1.0 to 2.9 body lengths. Thus, although juvenile Chinook salmon can express territorial behavior, territory size and the degree of territoriality expressed by individuals can be quite variable and context dependent.

Given that capacity can be defined over different lifestages and spatiotemporal scales, it follows that capacity and density dependence estimated at the population scale arise from habitat limitations at different locations and across multiple lifestages. In turn, density dependence at different points in the life cycle can be expressed through density dependent survival, growth, and movement (Independent Scientific Advisory Board, 2015). For example, limited spawning habitat can lead to redd superimposition, thereby reducing egg survival (McNeil, 1964; Maunder, 1997). For juvenile life stages, 
density dependent growth has been shown to be a common density dependent response to increased competition for food and space across multiple species and populations (Grant and Imre, 2005; Vincenzi and others, 2012; Walters and others, 2013; Independent Scientific Advisory Board, 2015; Matte and others, 2020). In turn, reduced growth at high densities combined with size-dependent survival has been hypothesized as a key mechanism giving rise to density dependent survival (Vincenzi and others, 2012; Walters and others, 2013). Given that size-dependent survival is a common observation in juvenile salmonids (Independent Scientific Advisory Board, 2015), the effect of capacity on density-dependent growth also has important consequences on survival. Last, competition for limited habitat can induce density-movement, forcing individuals to move downstream in search of available rearing habitat (Greene and Beechie, 2004; Connor and others, 2013; Copeland and others, 2014, Polivka, 2020). The degree to which density-dependent growth, movement, and survival contribute to population dynamics can vary among life stages and populations. For example, Walters and others (2013) found strong evidence of density-dependence growth and survival, but little evidence of density-dependent movement. In contrast, Connor and others (2013) found strong evidence of density-dependent movement in subyearling Snake River Chinook salmon.

The optimal approach to estimating capacity depends on the management question at hand, although embracing multiple approaches is likely to be more informative than taking a one-size-fits-all approach. For example, statistical life cycle models can be extremely useful for quantifying population level capacity through an entire life cycle (for example, Scheurell, 2019) or through a particular life stage (Tiffan and Perry, 2020). In addition, modeling life-cycle parameters as a function of covariates can provide insights into relevant water management factors that affect population dynamics (for example, riverflows during a particular life stage). Employing analyses at multiple scales of resolution can help to understand how dynamics at fine spatiotemporal scales (for example, effect of daily flow fluctuations in a particular reach) give rise to capacity limitations at the population/watershed scale.

Selecting the "optimal" methods for estimating capacity is challenging owing to complex spatiotemporal dynamics discussed above. Selecting one approach over another may be informed by multiple methods. First, estimates of capacity should be scaled to spatial and temporal scales relevant to water management actions under consideration. In this case, the USACE needs to understand the role of Willamette Project operations on habitat use and capacity of the Willamette River. Project operations occur on daily to weekly timescales, influencing habitat in different locations at different times. In turn, juvenile salmon fry, parr, pre-smolts and smolts survive, grow, and move downstream over time, and are thus influenced by project operations during these time periods.

Given goals of the USACE, insights about carrying capacity at the population level may be uninformative about water management actions at finer temporal and spatial scales acting on specific life stages at specific times and locations. In this case, using territory size as a proxy for capacity may provide a more direct index between fine-scale river management (for example, daily or weekly), spatial variation in habitat availability in a particular river reach, and capacity over shorter temporal and spatial scales. For example, territory size as a metric for capacity provides a natural application to 2D hydrodynamic models implemented on daily or weekly timescales.

Second, although capacity is an important metric, the method employed to estimate capacity may be less important than how capacity is used to understand effects of project operations on anadromous salmon populations of interest. As an endpoint, capacity carries no additional information beyond that afforded by available habitat area if capacity is a simple scalar transformation of habitat area (for example, capacity $=$ habitat area, mean territory size). However, capacity is the key population parameter that determines the degree to which juvenile salmon exhibit density-dependent demographic (for example, survival), biological (for example, growth), and behavioral (for example, movement) responses to given local population densities that ultimately affect population dynamics. Thus, gaining insight into the relative contribution of density dependent growth, movement, and survival provides a mechanistic linkage between project operations, capacity, and their ultimate effect on salmon population dynamics.

Third, perhaps the best approach to evaluate the effects of capacity on density-dependent dynamics is within a population model that hypothesizes different density-dependent mechanisms. Because capacity determines the magnitude of density dependent population dynamics, the process of constructing a population model helps to formalize (1) which density dependent mechanisms (growth, movement, or survival) are hypothesized to operate within a given population, (2) the life stages that experience density dependence, and (3) the functional relationships (that is, equations) and parameter values that determine precisely how capacity affects density dependence. For example, the series of decision support models being developed for structured decision making in the Willamette River (for example, DeWeber and Peterson, 2020) represent a population model in which river operations are linked to a $2 \mathrm{D}$ hydrodynamic model that is used to predict habitat capacity of anadromous juvenile salmonids. In alternative model structures, capacity can affect either density dependent movement or mortality (Peterson and others, 2020). The Stream Salmonid Simulator (Perry and others, 2018, 2019) and InSALMO (Railsback and others, 2013; Dudley, 2018) are examples of juvenile salmonid population models that include density dependence mechanisms, operate on daily timescales, and incorporate spatially explicit riverine habitat. The key feature of each of the models is that density dependent population dynamics at relatively fine spatial and temporal scales arise from managed river flows that influence available habitat and capacity at different locations and times. 


\section{Summary}

Decision-making related to flow management in impounded rivers is an important topic worldwide (Kennard and others, 2010) with significant socioeconomic and ecological consequences. Science that supports flow management decision-making has advanced significantly during the past four decades (Som and others, 2018; Naman and others, 2019, 2020). Initial tools such as PHABSIM have proven useful and been widely used but have also been shown to have limitations and received substantial criticism (Mathur and others, 1985; Orth, 1987; Beecher and others, 2010; Lancaster and Downes, 2010; Hayes and others, 2016). Newer tools have emerged that have strong predictive power (Som and others, 2018; Naman and others, 2020) but require large amounts of data for calibration. As such, resource managers face a difficult decision when selecting tools to assist flow management decision-making; devote minimal resources and use a conventional tool such as PHABSIM that can operate using transect data collection and literature-derived HSCs to produce results that may or may not accurately predict outcomes of flow-based actions; or invest substantially in in-basin data collection and model building efforts to develop a tool that may provide more predictive power. Decisions related to choosing which tool to use will depend on the metrics of interest, the risks or uncertainties associated with the different methods, and the risk tolerance of managers and stakeholders in the basin.

In the Willamette River Basin, flow management is a complex process due to competing interests (such as flood risk management, recreation, downstream flow, and water temperature targets) and implementation that occurs using a network of more than 12 reservoirs and dams located in multiple subbasins. Various life stages of ESA-listed Chinook salmon and steelhead are present in the basin during most months of the year and flow availability limitations often result in having to choose between flow scenarios that do not benefit juvenile and adult life stages equally, which further complicates the process. Given these complexities, the need for a quality predictive model is apparent. The two-dimensional hydrodynamic model that is currently being developed for the Willamette River Basin (White and others, 2020) provides several advantages over other modeling efforts previously completed including: (1) continuous bathymetry data have been collected in approximately 200 river kilometers located downstream from Project dams and additional data collection is underway in primary Willamette River tributaries downstream from these dams; (2) the model can be operated to account for water temperature and habitat requirements for various fish species and life stages; and (3) in-basin fish use data can be readily applied to validate model results. This model was developed specifically to assess flow management scenarios in the mainstem Willamette River and improves substantially on previous modeling efforts in the basin by utilizing a comprehensive bathymetry dataset. In-basin data collection will be imperative to refine model development and validate model predictions given the importance of this model to address flow-management questions in the basin in the future.

\section{References Cited}

Ayllón, D., Almodóvar, A., Nicola, G.G., Parra, I., and Elvira, B., 2012, Modelling carrying capacity dynamics for the conservation and management of territorial salmonids: Fisheries Research, v. 134-136, p. 95-103, accessed December 14, 2020, at https://doi.org/10.1016/j.fishres.2 012.08.004.

Baker, E.A., and Coon, T.G., 1997, Development and evaluation of alternative habitat suitability criteria for brook trout: Transactions of the American Fisheries Society, v. 126, no. 1, p. 65-76, accessed June 29, 2020, at https://doi.org/ 10.1577/1548-8659(1997)126<0065:DAEOAH>2.3.CO;2.

Barker, R.J., Schofield, M.R., Link, W.A., and Sauer, J.R., 2018, On the reliability of N-mixture models for count data: Biometrics, v. 74, no. 1, p. 369-377, accessed December 19, 2020, at https://doi.org/10.1111/biom.12734.

Beakes, M.P., Moore, J.W., Retford, N., Brown, R., Merz, J.E., and Sogard, S.M., 2014, Evaluating statistical approaches to quantifying juvenile Chinook salmon habitat in a regulated California River: River Research and Applications, v. 30, no. 2, p. 180-191, accessed November 15, 2020, at https://doi.org/10.1002/rra.2632.

Beecher, H.A., Caldwell, B.A., DeMond, S.B., Seiler, D., and Boessow, S.N., 2010, An empirical assessment of PHABSIM using long-term monitoring of coho salmon smolt production in Bingham Creek, Washington: North American Journal of Fisheries Management, v. 30, no. 6, p. 1529-1543, accessed November 15, 2020, at https://doi.org/10.1577/M10-020.1.

Beeman, J.W., Evans, S.D., Haner, P.V., Hansel, H.C., Hansen, A.C., Smith, C.D., and Sprando, J.M., 2014, Passage and survival probabilities of juvenile Chinook salmon at Cougar Dam, Oregon, 2012: U.S. Geological Survey Open-File Report 2014-1038, 64 p., accessed November 15, 2000, at https://doi.org/10.3133/ofr20141038.

Bond, M., Nodine, T., Sorel, M., Beechie, T., Pess, G., Myers, J., and Zabel, R., 2017, Estimates of UWR Chinook and steelhead spawning and rearing capacity above and below Willamette Project dams: Portland, Oregon, U.S. Army Corps of Engineers, Study Code APH-15-04-DET, 77 p.

Booker, D.J., and Dunbar, M.J., 2004, Application of physical habitat simulation (PHABSIM) modeling to modified urban river channels: River Research and Applications, v. 20, no. 2, p. 167-183, accessed December 1, 2020, at https://doi.org/10.1002/rra.742.

Bovee, K.D., 1982, A guide to stream habitat analyses using the instream flow incremental methodology: Washington, D.C., U.S. Fish and Wildlife Service, Report FSW/ OBS-82/26, Instream Flow Information Paper No. 12, FWS/ OBSERVATION 82/86, 248 p. 
Bovee, K.D., Lamb, B.L., Bartholomew, J.M., Stalnaker, C.B., Taylor, J., and Henricksen, J., 1998, Stream habitat analysis using the instream flow incremental methodology: U.S. Geological Survey, Biological Resources Division Information and Technology Report, USGS/ BRD-1998-0004, 131 p., accessed June 16, 2020, at https://apps.dtic.mil/dtic/tr/fulltext/u2/a361209.pdf.

Boyce, M.S., and McDonald, L.L., 1999, Relating populations to habitats using resource selection functions: Trends in Ecology \& Evolution, v. 14, no. 7, p. 268-272, accessed September 24, 2020, at https://doi.org/10.1016/S01695347(99)01593-1.

Brooks, R.P., 1997, Improving habitat suitability index models: Wildlife Society Bulletin, v. 25, no. 1, p. 163-167, accessed June 24, 2020, at http://www.jstor.org/ stable/3783299.

Castleberry, D.T., Cech, J.J., Erman, D.C., Hankin, D., Healey, M., Kondolf, G.M., Mangel, M., Mohr, M., Moyle, P.B., Nielsen, J., Speed, T.P., and Williams, J.G., 1996, Uncertainty and instream flow standards: Fisheries, v. 21, no. 8, p. 20-21, accessed June 30, 2020, at https://doi.org/ 10.1577/1548-8446-21-8.

Conder, A.L., and Annear, T.C., 1987, Test of weighted usable area estimates derived from a PHABSIM model of instream flow studies on trout streams: North American Journal of Fisheries Management, v. 7, no. 3, p. 339-350, accessed June 30, 2020, at https://doi.org/10.1577/1548-8659(1987)7 $<339$ :TOWUAE $>2.0$. CO;2.

Connor, W.P., Tiffan, K.F., Plumb, J.M., and Moffitt, C.M., 2013, Evidence for density-dependent changes in growth, downstream movement, and size of Chinook Salmon subyearlings in a large-river landscape: Transactions of the American Fisheries Society, v. 142, no. 5, p. 1453-1468, accessed January 6, 2021, at https://doi.org/10.1080/ 00028487.2013 .806953$.

Copeland, T., Venditti, D.A., and Barnett, B.R., 2014, The importance of juvenile migration tactics to adult recruitment in stream-type Chinook salmon populations: Transactions of the American Fisheries Society, v. 143, no. 6, p. 1460-1475, accessed January 6, 2021, at https://doi.org/10.1080/ 00028487.2014 .949011$.

DeWeber, J.T., and Peterson, J.T., 2020, Comparing environmental flow implementation options with structured decision making - Case study from the Willamette River, Oregon: Journal of the American Water Resources Association, v. 56, no. 4, p. 599-614, accessed December 14, 2020, at https://doi.org/10.1111/17521688.12845 .
Dorazio, R.M., Jelks, H.L., and Jordan, F., 2005, Improving removal-based estimates of abundance by sampling a population of spatially distinct subpopulations: Biometrics, v. 61, no. 4, p. 1093-1101, accessed November 9, 2020, at https://doi.org/10.1111/j.1541-0420.2005.00360.x.

Dudley, P.N., 2018, A salmonid individual-based model as a proposed decision support tool for management of a large regulated river: Ecosphere, v. 9, no. 1, p. e02074, accessed September 3, 2020, at https://doi.org/10.1002/ecs2.2074.

Ellis Ecological Services, Inc., and Santiam Water Control District, 2010, Effects of proposed diversion on fish, fish habitat, migration and water quality: Washington, D.C., Federal Energy Regulatory Commission, 213 p., accessed December 2018, at https://elibrary.ferc.gov/eLibrary/filelist? accession_number $=20100208-5067$.

Falke, J.A., Bailey, L.L., Fausch, K.D., and Bestgen, K.R., 2012, Colonization and extinction in dynamic habitats-An occupancy approach for Great Plains stream fish assemblage: Ecology, v. 93, no. 4, p. 858-867, accessed June 16, 2020, at https://doi.org/10.1890/11-1515.1.

Fausch, K., 1984, Profitable stream positions for salmonidsRelating specific growth rate to net energy gain: Canadian Journal of Zoology, v. 62, no. 3, p. 441-451, accessed July 15, 2020, at https://doi.org/10.1139/z84-067.

Gan, K., and McMahon, T., 1990, Variability of results from the use of PHABSIM in estimating habitat area: Regulated Rivers, v. 5, no. 3, p. 233-239, accessed June 24, 2020, at https://doi.org/10.1002/rrr.3450050304.

Gard, M., 2005, Variability in flow-habitat relationships as a function of transect number for PHABSIM modeling: River Research and Applications, v. 21, no. 9, p. 1013-1019, accessed December 20, 2020, at https://doi.org/ $10.1002 /$ rra.862.

Grant, J.W.A., and Imre, I., 2005, Patterns of densitydependent growth in juvenile stream-dwelling salmonids: Journal of Fish Biology, v. 67, p. 100-110, accessed September 14, 2020, at https://doi.org/10.1111/j.00221112.2005.00916.x.

Grant, J.W.A., and Kramer, D.L., 1990, Territory size as a predictor of the upper limit to population density of juvenile salmonids in streams: Canadian Journal of Fisheries and Aquatic Sciences, v. 47, no. 9, p. 1724-1737, accessed November 14, 2020, at https://doi.org/10.1139/f90-197.

Greene, C.M., and Beechie, T.J., 2004, Consequences of potential density-dependent mechanisms on recovery of ocean-type Chinook salmon (Oncorhynchus tshawytscha): Canadian Journal of Fisheries and Aquatic Sciences, v. 61, no. 4, p. 590-602, accessed September 14, 2020, at https://doi.org/10.1139/f04-024. 
Hatten, J.R., Batt, T.R., Connolly, P.J., and Maule, A.G., 2014, Modeling effects of climate change on the Yakima River salmonid habitats: Climatic Change, v. 124, p. 427-439, accessed December 14, 2020, at https://doi.org/10.1007/ s10584-013-0980-4.

Hatten, J.R., Batt, T.R., Scoppettone, G.G., and Dixon, C.J., 2013, An ecohydraulic model to identify and monitor Moapa dace habitat: PLoS One, v. 8, no. 2, 12 p., accessed July 1, 2020, at https://doi.org/10.1371/ journal.pone.0055551.

Hatten, J.R., Parsley, M.J., Barton, G.J., Batt, T.R., and Fosness, R.L., 2018, Substrate and flow characteristics associated with White Sturgeon recruitment in the Columbia River Basin: Heliyon, v. 4, no. 5, 28 p., accessed December 1, 2020, at https://doi.org/10.1016/j.heliyon.2 018.e00629.

Hatten, J.R., Tiffan, K.F., Anglin, D.R., Haeseker, S.L., Skalicky, J.J., and Schaller, H., 2009, A spatial model to assess the effects of hydropower operations on Columbia River fall Chinook salmon spawning habitat: North American Journal of Fisheries Management, v. 29, no. 5, p. 1379-1405, accessed September 15, 2020, at https://doi.org/10.1577/M08-053.1.

Hayes, J.W., and Jowett, I.G., 1994, Microhabitat models of large drift-feeding brown trout in three New Zealand rivers: North American Journal of Fisheries Management, v. 14 , no. 4, p. 710-725, accessed October 21, 2020, at https://doi.org/10.1577/1548-8675(1994)014<0710:MMOL $\mathrm{DF}>2.3 . \mathrm{CO} ; 2$.

Hayes, J.W., Goodwin, E., Shearer, K.A., Hay, J., and Kelly, L., 2016, Can weighted useable area predict flow requirements of drift-feeding salmonids? Comparison with a net rate of energy intake model incorporating drift-flow processes: Transactions of the American Fisheries Society, v. 145 , no. 3, p. 589-609, accessed December 20, 2020, at https://doi.org/10.1080/00028487.2015.1121923.

Hayes, J.W., Goodwin, E.O., Shearer, K.A., and Hicks, D.M., 2019, Relationship between background invertebrate drift concentration and flow over natural flow recession and prediction with a drift transport model: Canadian Journal of Fisheries and Aquatic Sciences, v. 76, no. 6, p. 871-885, accessed June 24, 2020, at https://doi.org/10.1139/cjfas2017-0340.

Hilborn, R., and Walters, C.J., eds., 2013, Quantitative fisheries stock assessment - Choice, dynamics, and uncertainty: New York, Springer Science \& Business Media, 570 p.
Hughes, N.F., and Dill, L.M., 1990, Position choice by drift feeding salmonids - A model and test for arctic grayling (Thymallus arcticus) in subarctic mountain streams, interior Alaska: Canadian Journal of Fisheries and Aquatic Sciences, v. 47, no. 10, p. 2039-2048, accessed September 20, 2020, at https://doi.org/10.1139/f90-228.

Hulse, D., and Gregory, S.V., 2004, Integrating resilience into floodplain restoration: Urban Ecosystems, v. 7, no. 3, p. 295-314, accessed June 18, 2020, at https://doi.org/ 10.1023/B:UECO.0000044041.94705.52.

Hulse, D., Enright, C., and Branscomb, A., 2017, Willamette River floodplain 100 meter slices framework geospatial data (ver. 1, June 01, 2017) [data set]: University of Oregon, Institute for a Sustainable Environment, accessed December 3, 2020, at https://doi.org/10.7267/5712MC568.

Independent Scientific Advisory Board, 2015, Densitydependence and its implications for fish management and restoration programs in the Columbia River Basin: Portland, Oregon, Independent Scientific Advisory Board Report 2015-1, 246 p., accessed June 18, 2020, at: https://www.nwcouncil.org/fish-and-wildlife/ fw-independent-advisory-committees/independentscientific-advisory-board/density-dependence-and-itsimplications-for-fish-management-and-restoration-in-thecolumbia-river-basin-and-july-2016-addendum.

Johnson, C.J., Nielsen, S.E., Merrill, E.H., McDonald, T.L., and Boyce, M.S., 2006, Resource selection functions based on use-availability data-Theoretical motivation and evaluation methods: The Journal of Wildlife Management, v. 70, no. 2, p. 347-357, accessed December 8, 2020, at https://doi.org/10.2193/0022-541X(2006)70[347:RSFB OU]2.0.CO;2.

Keefer, M.L., Taylor, G.A., Garletts, D.F., Helms, C.K., Gauthier, G.A., Pierce, T.M., and Caudill, C.C., 2013, Highhead dams affect downstream fish passage timing and survival in the Middle Fork Willamette River: River Research and Applications, v. 29, no. 4, p. 483-492, accessed July 22, 2020, at https://doi.org/10.1002/rra.1613.

Kennard, M.J., Pusey, B.J., Olden, J.D., Mackay, S.J., Stein, J.L., and Marsh, N., 2010, Classification of natural flow regimes in Australia to support environmental flow management: Freshwater Biology, v. 55, no. 1, p. 171-193, accessed January 11, 2021, at https://doi.org/10.1111/j.13652427.2009.02307.x. 
Kock, T.J., Beeman, J.W., Hansen, A.C., Hansel, H.C., Hansen, G.S., Hatton, T.W., Kofoot, E.E., Sholtis, M.D., and Sprando, J.M., 2015, Behavior, passage, and downstream migration of juvenile Chinook salmon from Detroit Reservoir to Portland, Oregon, 2014-15: U.S. Geological Survey Open-File Report 2015-1220, 30 p., accessed July 1, 2019, at https://doi.org/10.3133/ofr20151220.

Lancaster, J., and Downes, B.J., 2010, Linking the hydraulic world of individual organisms to ecological processesPutting ecology into ecohydraulics: River Research and Applications, v. 26, no. 4, p. 385-403, accessed January 11, 2021, at https://doi.org/10.1002/rra.1274.

Liermann, M.C., Sharma, R., and Parken, C.K., 2010, Using accessible watershed size to predict management parameters for Chinook salmon, Oncorhynchus tshawytscha, populations with little or no spawner-recruit data-A Bayesian hierarchical modelling approach: Fisheries Management and Ecology, v. 17, no. 1, p. 40-51, accessed June 12, 2020, at https://doi.org/10.1111/j.1365-2400.2009.00719.x.

MacKenzie, D.I., Nichols, J.D., Lachman, G.B., Droege, S., Royle, J.A., and Langtimm, C.A., 2002, Estimating site occupancy rates when detection probabilities are less than one: Ecology, v. 83, no. 8, p. 2248-2255, accessed June 13, 2020, at https://doi.org/10.1890/0012-9658(2002)083 [2248:ESORWD]2.0.CO;2.

Mathur, D., Bason, W.H., Purdy, E.J., Jr., and Silver, C.A., 1985, A critique of the instream flow incremental methodology: Canadian Journal of Fisheries and Aquatic Sciences, v. 42 , no. 4 , p. $825-831$, accessed January 11,2021 , at https://doi.org/10.1139/f85-105.

Manly, B.F.J., McDonald, L.L., and Thomas, D.L., 1992, Resource selection by animals - Statistical design and analysis for field studies: London, Chapman and Hall, 177 p.

Matte, J.M., Fraser, D.J., and Grant, J.W., 2020, Population variation in density-dependent growth, mortality and their trade-off in a stream fish: Journal of Animal Ecology, v. 89 , no. 2, p. 541-552, accessed December 9, 2020, at https://doi.org/10.1111/1365-2656.13124.

Maunder, M.N., 1997, Investigation of density dependence in salmon spawner-egg relationships using queueing theory: Ecological Modelling, v. 104, no. 2-3, p. 189-197, accessed September 2, 2020, at https://doi.org/10.1016/S03043800(97)00126-9.

McIntosh, B.A., Clark, S.E., and Sedell, J.R., 1990, Summary Report for Bureau of Fisheries Stream Habitat Surveys - Yakima River Basin, 1934-1942: Portland, Oregon, U.S. Department of Energy and Bonneville Power Administration, accessed September 2, 2020, at https://doi.org/10.2172/925615.
McNeil, W.J., 1964, Redd superimposition and egg capacity of pink salmon spawning beds: Journal of the Fisheries Board of Canada, v. 21, no. 6, p. 1385-1396, accessed June 18, 2020, at https://doi.org/10.2172/92561510.1139/f64-119.

Moir, H.J., Gibbins, C.N., Soulsby, C., and Youngson, A.F., 2005, PHABSIM modeling of Atlantic salmon spawning habitat in an upland stream-Testing the influence of habitat suitability indices on model output: River Research and Applications, v. 21, no. 9, p. 1021-1034, accessed July 21, 2020, at https://doi.org/10.1002/rra.869.

Moussalli, E., and Hilborn, R., 1986, Optimal stock size and harvest rate in multistage life history models: Canadian Journal of Fisheries and Aquatic Sciences, v. 43, no. 1, p. 135-141, accessed November 2, 2020, at https://doi.org/ 10.1139/f86-014.

Naman, S.M., Rosenfeld, J.S., Neuswanger, J.R., Enders, E.C., and Eaton, B.C., 2019, Comparing correlative and bioenergetics-based habitat suitability models for drift-feeding fishes: Freshwater Biology, v. 64, no. 9, p. 1613-1626, accessed July 2, 2020, at https://doi.org/10.1111/fwb.13358.

Naman, S.M., Rosenfeld, J.S., Neuswanger, J.R., Enders, E.C., Hayes, J.W., Goodwin, E.O., Jowett, I.G., and Eaton, B.C., 2020, Bioenergetic habitat suitability curves for instream flow modeling - Introducing user-friendly software and its potential applications: Fisheries, v. 45, no. 11, p. 605-613, accessed January 11, 2021, at https://doi.org/10.1002/ fsh.10489.

Neuswanger, J.R., Wipfli, M.S., Rosenberger, A.E., and Hughes, N.F., 2016, Measuring fish and their physical habitats - Versatile 2D and 3D video techniques with user-friendly software: Canadian Journal of Fisheries and Aquatic Sciences, v. 73, no. 12, p. 1861-1873, accessed June 13, 2020, at https://doi.org/10.1139/cjfas-2016-0010.

National Marine Fisheries Service, 2008, Endangered Species Act Section 7(a)(2) Consultation, Biological Opinion and Magnuson-Stevens Fishery Conservation and Management Act Essential Fish Habitat Consultation: Portland, Oregon, National Oceanic and Atmospheric Administration Fisheries Log Number F/NWR/2000/02117, 280 p.

National Marine Fisheries Service, 1999a, Endangered and threatened species-Threatened status for three Chinook salmon evolutionarily significant units (ESUs) in Washington and Oregon, and endangered status of one Chinook salmon ESU in Washington: Federal Register, v. 64 , no. 56 , p. $14308-14328$.

National Marine Fisheries Service, 1999b, Endangered and threatened species-Threatened status for two ESUs of steelhead in Oregon and Washington: Federal Register, v. 64, no. 28 , p. 14517-14528. 
Orth, D.J., 1987, Ecological considerations in the development and application of instream flow-habitat models: Regulated Rivers, v. 1, no. 2, p. 171-181, accessed January 11, 2021, at https://doi.org/10.1002/rrr.3450010207.

Parken, C.K., McNicol, R.E., and Irvine, J.R., 2006, Habitatbased methods to estimate escapement goals for data limited Chinook salmon stocks in British Columbia, 2004: Nanaimo, British Columbia, Fisheries and Oceans Canada, 74 p., accessed December 8, 2020, at https://www.arlis.org/ docs/vol1/K/234144596.pdf.

Perry, R.W., Plumb, J.M., Jones, E.C., Som, N.A., Hardy, T.B., and Hetrick, N.J., 2019, Application of the Stream Salmonid Simulator (S3) to Klamath River fall Chinook salmon (Oncorhynchus tshawytscha), California-Parameterization and calibration: U.S. Geological Survey Open-File Report 2019-1107, 89 p., accessed September 21, 2020, at https://doi.org/10.3133/ofr20191107.

Perry, R.W., Plumb, J.M., Jones, E.C., Som, N.A., Hetrick, N.J., and Hardy, T.B., 2018, Model structure of the stream salmonid simulator (S3) - A dynamic model for simulating growth, movement, and survival of juvenile salmonids: U.S. Geological Survey Open-File Report 2018-1056, 32 p., accessed September 21, 2020, at https://doi.org/10.3133/ ofr20181056.

Peterson, J.T., Pease, J.E., Whitman, L., White, J., StrattonGarvin, L., Rounds, S., and Wallick, R., 2020, Willamette instream flow project-Integrated tools for the evaluation of alternative flow management strategies-Willamette Fisheries Science Review, Corvallis, Oregon, 2020, Presentation: Corvallis, Oregon, Columbia River Operational Hydrometeorological Management System, 29 p., accessed November 15, 2020, at http://pweb.crohms.org/ tmt/documents/FPOM/2010/Willamette_Coordination/ WFSR/Day 1_1455_Peterson_Willamette Instream Flow Project_WFSR 2020 .pdf.

Polivka, C.M., 2020, Habitat affinity and density-dependent movement as indicators of fish habitat restoration efficacy: Ecosphere, v. 11, no. 6, p. e03166, accessed December 21, 2020, at https://doi.org/10.1002/ecs2.3166.

Quinn, T.J., and Deriso, R.B., 1999, Quantitative fish dynamics: Oxford, United Kingdom, Oxford University Press, $560 \mathrm{p}$.

R2 Resource Consultants, Inc., 2005, Willamette Valley anadromous fish and bull trout habitat assessment: Portland, Oregon, U.S. Army Corps of Engineers, 38 p.
R2 Resource Consultants, Inc., 2009, Willamette River Basin habitat assessment data summary report: Portland, Oregon, U.S. Army Corps of Engineers, 65 p.

R2 Resource Consultants, Inc., 2014, Evaluation of habitatflow relationships for Spring Chinook and winter steelhead in the North and South Santiam Rivers, Oregon: Portland, Oregon, U.S. Army Corps of Engineers, 148 p.

Railsback, S.F., 2016, Why it is time to put PHABSIM out to pasture: Fisheries, v. 41 , no. 12, p. 720-725, accessed November 13, 2020, at https://doi.org/10.1080/03632415.20 16.1245991 .

Railsback, S.F., Gard, M., Harvey, B.C., White, J.L., and Zimmerman, J.K.H., 2013, Contrast of degraded and restored stream habitat using an individual-based salmon model: North American Journal of Fisheries Management, v. 33, no. 2, p. 384-399, accessed at September 21, 2020, at https://doi.org/10.1080/02755947.2013.765527.

River Design Group, Inc., and HDR, Inc., 2015, Evaluation of the relationship between river flow and fish habitat availability in the Middle Fork of the Willamette and McKenzie Rivers: Portland, Oregon, U.S. Army Corps of Engineers, $218 \mathrm{p}$.

Rosenfeld, J.S., Bouwes, N., Wall, C.E., and Naman, S.M., 2014, Successes, failures, and opportunities in the practical application of drift-foraging models: Environmental Biology of Fishes, v. 97, no. 5, p. 551-574, accessed July 13, 2020, at https://doi.org/10.1007/s10641013-0195-6.

Rosenfeld, J., Beecher, H., and Ptolemy, R., 2016, Developing bioenergetic-based habitat suitability curves for instream flow models: North American Journal of Fisheries Management, v. 36, no. 5, p. 1205-1219, accessed May 3, 2020, at https://doi.org/10.1080/02755947.2016.1198285.

Royle, J.A., 2004, N-mixture models for estimating population size from spatially replicated counts: Biometrics, v. 60 , no. 1, p. 108-115, accessed November 2, 2020, at https://doi.org/10.1111/j.0006-341X.2004.00142.x.

Royle, J.A., Chandler, R.B., Yackulic, C., and Nichols, J.D., 2012, Likelihood analysis of species occurrence probability from presence-only data for modeling species distributions: Methods in Ecology and Evolution, v. 3, no. 3, p. 545-554, accessed May 3, 2020, at https://doi.org/10.1111/j.2041210X.2011.00182.x. 
Scheurell, M.D., 2019, Development and application of an integrated population model for Chinook salmon in the Willamette River Basin: Portland Oregon, U.S. Army Corps of Engineers, prepared by the National Oceanic and Atmospheric Administration Fisheries, 59 p.

Seber, G.A.F., 1982, The Estimation of Animal Abundance and Related Parameters 2nd ed.: London, Edward Arnold, 25 p.

Sethi, S.A., and Benolkin, E., 2013, Detection efficiency and habitat use to inform inventory and monitoring effortsJuvenile coho salmon in the Knik River Basin, Alaska: Ecology Freshwater Fish, v. 22, no. 3, p. 398-411, accessed July 13, 2020, at https://doi.org/10.1111/eff.12034.

Shirvell, C.S., 1989, Ability of PHABSIM to predict Chinook salmon spawning habitat: Regulated Rivers, v. 3, no. 1, p. 277-289, accessed June 18, 2020, at https://doi.org/ 10.1002/rrr.3450030127.

Som, N.A., Goodman, D.H., Perry, R.W., and Hardy, T.B., 2016, Habitat suitability criteria via parametric distributions - Estimation, model selection and uncertainty: River Research and Applications, v. 32, no. 5, p. 1128-1137, accessed December 3, 2020, at https://doi.org/10.1002/ rra.2900.

Som, N.A., Perry, R.W., Jones, E.C., De Juilio, K., Petros, P., Pinnix, W.D., and Rupert, D.L., 2018, N-mix for fish_Estimating riverine salmonid habitat selection via N-mixture models: Canadian Journal of Fisheries and Aquatic Sciences, v. 75, no. 7, p. 1048-1058, accessed July 3, 2020, at https://doi.org/10.1139/cjfas-2017-0027.

Taylor, E.B., 1990, Phenotypic correlates of life-history variation in juvenile chinook salmon, Oncorhynchus tshawytscha: Journal of Animal Ecology, v. 59, no. 2, p. 455-468, accessed September 3, 2020, at https://doi.org/ $10.2307 / 4874$.

Thomas, J.A., and Bovee, K.D., 1993, Application and testing of a procedure to evaluate transferability of habitat suitability criteria: Regulated Rivers, v. 8, no. 3, p. 285-294, accessed June 29, 2020, at https://doi.org/10.1002/ rrr.3450080307.

Tiffan, K., and Perry, R., 2020, Research, monitoring, and evaluation of emerging issues and measures to recover the Snake River fall Chinook salmon ESU: Portland, Oregon, Bonneville Power Administration, 131 p, accessed December 15, 2020, at https:/www.cbfish.org/ Document.mve/Viewer/P176701.
Tiffan, K.T., Clark, L.O., Garland, R.D., and Rondorf, D.W., 2006, Variables influencing the presence and absence of subyearling fall Chinook salmon in shoreline habitats of the Hanford Reach, Columbia River: North American Journal of Fisheries Management, v. 26, no. 2, p. 351-360, accessed September 3, 2020, at https://doi.org/10.1577/M04-161.1.

Tiffan, K.F., Garland, R.D., and Rondorf, D.W., 2002, Quantifying flow-dependent changes in subyearling fall Chinook salmon rearing habitat using two-dimensional spatially explicit modeling: North American Journal of Fisheries Management, v. 22, no. 3, p. 713-726.

Vincenzi, S., Satterthwaite, W.H., and Mangel, M., 2012, Spatial and temporal scale of density-dependent body growth and its implications for recruitment, population dynamics and management of stream-dwelling salmonid populations: Reviews in Fish Biology and Fisheries, v. 22, no. 3, p. 813-825, accessed November 20, 2020, at https://doi.org/10.1007/s11160-011-9247-1.

Wall, C.E., Bouwes, N., Wheaton, J.M., Saunders, W.C., and Bennett, S.N., 2016, Net rate of energy intake predicts reach-level steelhead (Oncorhynchus mykiss) densities in diverse basins from a large monitoring program: Canadian Journal of Fisheries and Aquatic Sciences, v. 73, no. 7, p. 1081-1091, at https://doi.org/10.1139/cjfas-2015-0290.

Wallick, R., Jones, K., O’Connor, J., and Keith, M., 2013, Geomorphic and vegetation processes of the Willamette River floodplain, Oregon-Current understanding and unanswered questions: U.S. Geological Survey Open-File Report 2013-1246, 70 p., accessed December 14, 2020, at https://doi.org/10.3133/ofr20131246.

Walters, A.W., Copeland, T., and Venditti, D.A., 2013, The density dilemma-Limitations on juvenile production in threatened salmon populations: Ecology Freshwater Fish, v. 22, no. 4, p. 508-519, accessed June 13, 2020, at https://doi.org/10.1111/eff.12046.

Wakeley, J.S., 1988, A method to create simplified versions of existing habitat suitability index (HSI) models: Environmental Management, v. 12, no. 1, p. 79-83, accessed June 29, 2020. 10.1007/BF01867379.

Wenger, S.J., Peterson, J.T., Freeman, M.C., Freeman, B.J., and Homans, D.D., 2008, Stream fish occurrence in response to impervious cover, historic land use, and hydrogeomorphic factors: Canadian Journal of Fisheries and Aquatic Sciences, v. 65, no. 7, p. 1250-1264, accessed September 3, 2020, at https://doi.org/10.1139/F08-046. 
White, J., Wallick, R., Overstreet, B., and Gordon, G., 2020, Where, when, and how much salmonid habitat is available on the Willamette River-State of the Willamette workshop, Corvallis, Oregon, January 15-16, 2020, Presentation: Portland, Oregon, U.S. Army Corps of Engineers, 61 p., accessed December 12, 2020 at, http://pweb.crohms.org/ tmt/documents/FPOM/2010/Willamette_Coordination/ WFSR/Day\%201_1315_White_Willamette\%20RIver\%20 Modeling\%20For\%20Salmon\%20Habitat_WFSR $\% 20$ 2020.pdf.

Whitman, L.D., Schroeder, R.K., and Friesen, T.A., 2017, Evaluating migration timing and habitat for juvenile Chinook salmon and winter steelhead in the mainstem Willamette River and major spawning tributaries: Portland, Oregon, U.S. Army Corps of Engineers, 32 p.

Williams, J.G., 2001, Testing models for instream flow assessment: Fisheries (Bethesda, Md.), v. 26, no. 12, p. 1-48, accessed November 3, 2020, at https://doi.org/10.1577/ 1548-8446-26-12.
Williams, J.G., 2010, Lost in space, the sequel—Spatial sampling issues with 1-D PHABSIM: River Research and Applications, v. 26, no. 3, p. 341-352, accessed July 14, 2020, at https://doi.org/10.1002/rra.1258.

Williams, J.G., 2013, Bootstrap sampling is with replacement-A comment on Ayllon et al (2011): River Research and Applications, v. 29, no. 3, p. 399-401, accessed September 3, 2020, at https://doi.org/10.1002/ rra.1605.

Williams, J.E., 2014, Habitat relationships of native and nonnative fishes of the Willamette River, Oregon: Corvallis, Oregon, Oregon State University, Master's Thesis, 139 p., accessed December 14, 2020, at https://ir.library.oregon state.edu/xmlui/handle/1957/49883.

Yi, Y., Cheng, X., Yang, Z., Wieprecht, S., Zhang, S., and $\mathrm{Wu}$, Y., 2017, Evaluating the ecological influence of hydraulic projects - A review of aquatic habitat suitability models: Renewable \& Sustainable Energy Reviews, v. 68, p. 748-762, accessed November, 2018, at https://doi.org/ 10.1016/j.rser.2016.09.138. 
Publishing support provided by the U.S. Geological Survey Science Publishing Network, Tacoma Publishing Service Center

For more information concerning the research in this report, contact the Director, Western Fisheries Research Center

U.S. Geological Survey

6505 NE 65th Street

Seattle, Washington 98115-5016

https://www.usgs.gov/centers/wfrc 


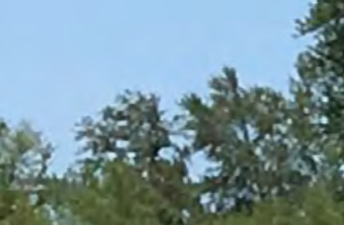
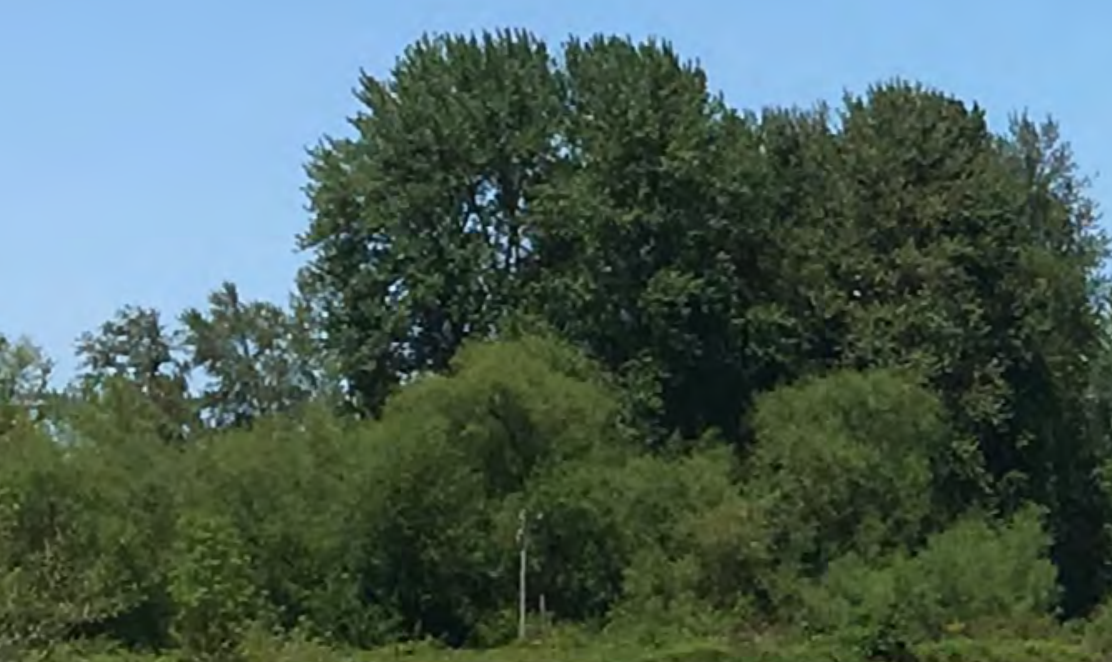

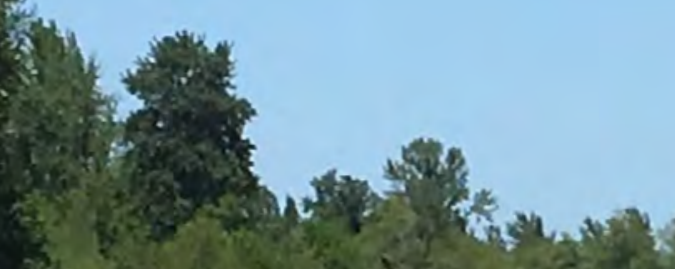

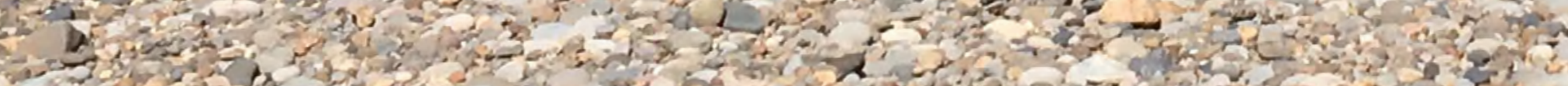

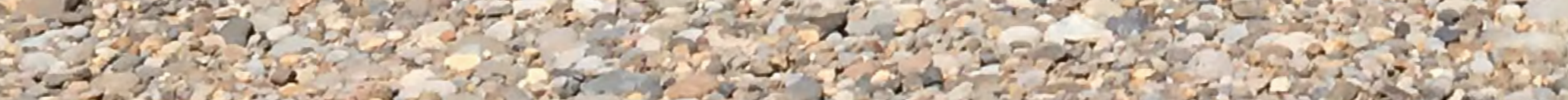

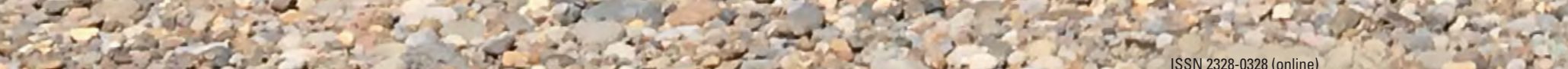

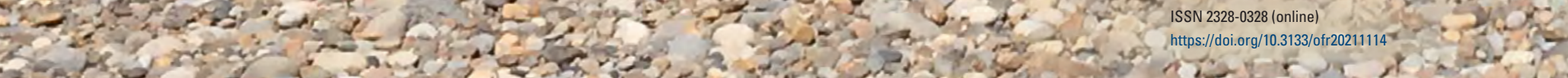

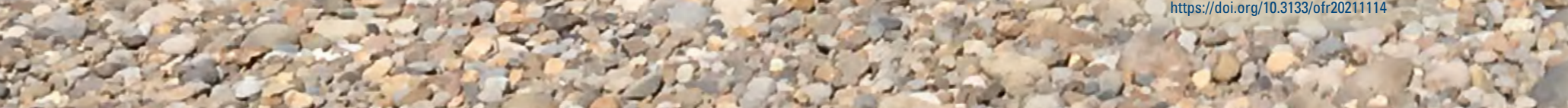

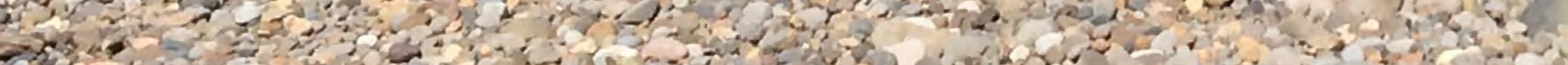

